University of Louisville

ThinkIR: The University of Louisville's Institutional Repository

Electronic Theses and Dissertations

$5-2007$

\title{
Transnational advocacy networks in the international system : lessons from Ecuador.
}

Isabella Marie Christensen 1977-

University of Louisville

Follow this and additional works at: https://ir.library.louisville.edu/etd

\section{Recommended Citation}

Christensen, Isabella Marie 1977-, "Transnational advocacy networks in the international system : lessons from Ecuador." (2007). Electronic Theses and Dissertations. Paper 249.

https://doi.org/10.18297/etd/249

This Master's Thesis is brought to you for free and open access by ThinkIR: The University of Louisville's Institutional Repository. It has been accepted for inclusion in Electronic Theses and Dissertations by an authorized administrator of ThinkIR: The University of Louisville's Institutional Repository. This title appears here courtesy of the author, who has retained all other copyrights. For more information, please contact thinkir@louisville.edu. 


\title{
TRANSNATIONAL ADVOCACY NETWORKS \\ IN THE INTERNATIONAL SYSTEM: \\ LESSONS FROM ECUADOR
}

\author{
By \\ Isabella Christensen \\ B.A., University of Louisville, 2004 \\ Dr. Okbazghi Yohannes, Advisor

\begin{abstract}
A Thesis
Submitted to the Faculty of the

Graduate School of the University of Louisville in Partial Fulfillment of the Requirements for the Degree of
\end{abstract} \\ Master of Arts \\ Department of Political Science \\ University of Louisville \\ Louisville, Kentucky
}

May 2007 
TRANSNATIONAL ADVOCACY NETWORKS

IN THE INTERNATIONAL SYSTEM:

LESSONS FROM ECUADOR

$$
\text { By }
$$

Isabella Christensen

B.A., University of Louisville, 2004

A Thesis Approved on

April 04, 2007

by the following Thesis Committee:

Thesis Director 


\section{ACKNOWLEDGMENTS}

My sincerest thanks to Professor Okbazghi Yohannes for his visionary mentoring and good humor. I am also grateful to Professor Lauren Heberle who alerted me to the intersections between environment and politics and to Professor Susan Matarese for her insights into social dynamics. I could not have asked for a better thesis committee. I have also enjoyed significant support from the Department of Political Science, and particularly from Dr. Laurie Rhodebeck. Also not be forgotten for their help in establishing the foundations of this project are faculty from the University of New Mexico, especially Dr.William Stanley, Dr.Carole Nagengast and Dr. Naomi Gabriela Schwartz. Finally, humble thanks to my parents and husband for their patience, support and love. 


\title{
ABSTRACT \\ TRANSNATIONAL ADVOCACY NETWORKS \\ IN THE INTERNATIONAL SYSTEM: \\ LESSONS FROM ECUADOR
}

\author{
Isabella Christensen
}

May 12, 2007

The transnational advocacy campaign against Ecuador's second oil-transporting pipeline, the Oleoducto de Crudo Pesado, had no impact on that state's endorsement of the project and only a negligible effect on related social and environmental policies. This outcome is at odds with the theoretical formulation advanced by Keck and Sikkink which holds that certain transnational advocacy campaigns can act as agents of state-level policy changes. While Keck and Sikkink locate causal variables of campaign outcome on the levels of the campaign and the state, the Oleoducto de Crudo Pesado case signals the need to further incorporate international-level analysis and to investigate the implications of this third dimension for transnational advocacy campaign outcome. The case study presented herein suggests that theories of transnational advocacy sacrifice predictive power by ignoring the extent to which international economic and political structures can shape the preferences of states. 
TABLE OF CONTENTS

PAGE

ACKNOWLEDGMENTS........................................... iii

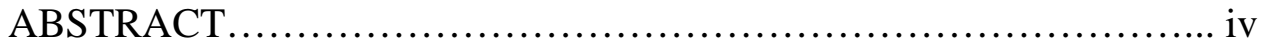

INTRODUCTION................................................. 1

ACTIVISTS BEYOND BORDERS:

A Brief Introduction to Dominant Theoretical Concepts .................. 3

TRANSNATIONAL ACTIVISM IN ECUADOR: An Overview......... 10

CASE ANALYSIS: Methods and Caveats............................. 14

CASE ANALYSIS: Empirical Challenges.............................. 19

CASE: SOTE Era, 1964 - 1990

Actors and Institutional Capacity................................ 26

Social and Environmental Impact.............................. 28

Analysis..................................................... 36

CASE: OCP Era, 1989 - 2003

Actors and Institutional Capacity............................... 44

Social and Environmental Impact.............................. 50

Analysis..................................................... 55

FINAL DISCUSSION.................................................... 74

RESEARCH PROPOSAL........................................... 79

REFERENCES ...................................................... 85 
APPENDIX: Acronyms......................................... 95

CURRICULUM VITAE........................................... 97 


\section{INTRODUCTION}

Transnational advocacy network theorists have developed a rich literature that attends to the network or its immediate (domestic) target. Intensive focus on these levels of analysis has translated into a wealth of writings on the emergence and sustainability of campaigns, the constructive dynamics of campaigns, and challenges presented by grassroots campaigning to democratic consolidation, for example. While theorists generally expect that actors from the international community will intervene in disputes between state and sub-state actors, few writers treat seriously this “third actor.” Rather, it often seems that transnational advocacy scholars have simply transplanted social movement theories to the international level without accounting for the additional dimension and attendant interaction dynamics. Efforts to graft social movement theories onto the international level have contributed to a static and superficial understanding of the potential impact of international-level actors on campaign outcome.

There are good reasons to remedy this lopsided approach. Disregard for the pivotal international actor has undermined the predictive power and therefore the utility of these theories. Furthermore, examination of the significance of international actors will encourage penetrating questions about the foundations and characteristics of the current global system, both political and economic, and the implications of its structure for the practice and conception of transnational advocacy. 
The aim of this thesis is to build on existing transnational advocacy literature by further incorporating international-level actors and by arguing that transnational advocacy practice and theory must confront the complexities of the international political economy. The first step towards this goal is to present the reader with a brief review of the principal findings of this theoretical approach as they were developed by Keck and Sikkink in Activists Beyond Borders. Theoretical discussion will be followed by a case study application with the purpose of demonstrating the predictive deficiencies of campaign-level analysis. A transnational campaign focused on Ecuador and its petroleum industry will serve here as the case study. This narrative will be presented in two parts in order facilitate separate examinations of the campaign's origin and outcome; analysis of relevant theoretical and methodological considerations will follow each part. The concluding sections will comment on the value and possible directions of future research.

A transnational campaign that aims to induce a norm shift on the national level is unlikely to succeed if the desired outcome substantially challenges dominant international values and the political structures that support them. In the end, specific, internationallevel constellations of costs and benefits associated with a target's response to campaign demands would seem to have as much to do with the outcome as campaign execution, the quality of the network or the nature of the campaign issue. With this in mind, it is reasonable to ponder the significance of the global political economy for transnational activism in general; certainly, this is one factor that is common to all transnational campaigns, and as such it provides a jumping-off point for future research into the viability of this approach. 


\section{ACTIVISTS BEYOND BORDERS: A Brief Introduction to Dominant Theoretical Concepts}

The term ‘Transnational Action Network’ or TAN, was adopted by Margaret Keck and Kathryn Sikkink in their 1998 book, Activists Beyond Borders. In this wellreceived work, the authors used the term to refer to any network, or loose and fluid configuration, of activists who, whether tied primarily to national or international political arenas, collaborate in order to convince national governments to comply with activists' demands and, by extension, with international norms and democratic principles.

Humanitarian border-crossing was not, in 1998, a new phenomenon, but Keck and Sikkink were able to distill from the long history of TAN practice a fresh theoreticallybased understanding of the dynamics of TANs. Their discussion was compelling enough to inspire reactions from numerous scholars across disciplines, greatly expanding this body of political science research while also preserving its distinct in its blending of domestically-oriented Social Movement and International Relations theories and its unapologetically normative bent. The principal endeavors of this literature have been to 1) define this brand of activism by identifying the actors, strategies and goals involved and, 2) develop a theory that accounts for the variation in outcome of such activism. This brief introductory review of the literature treats Keck and Sikkink’s formulation as representative of the literature at large; more recent formulations can be approached as variations on their theme. 
Two years after its publication, Activists Beyond Borders earned Margaret Keck and Kathryn Sikkink the 2000 Grawemeyer Prize for Ideas Improving World Order. ${ }^{1}$ As the title of the award suggests, this work is decidedly focused on the potential of normative political activism for affecting social and political change on an international scale. In essence, Keck and Sikkink argue that there exists a community of activists that utilizes both domestic and foreign resources to induce national governments to abandon certain policies and positions deemed repressive, undemocratic, or otherwise ethically unacceptable. As such, the authors argue, this specific form of activism has great potential for transforming state behavior since domestic policy alignment with international norms is expected to lead to internalization of the preferred orientation.

The authors discuss the normative beliefs that underpin the existence and actions of a TAN: participants' goals, the constructive effects of normative work on the emergence and development of a TAN or of a single campaign, and so on. They link this discussion to a consideration of the types of soft and normative-based power (or "politics") that TANs can draw on in the absence of traditional hard power: Informational, Symbolic, Leverage, or Accountability. In case-study format, they describe the current and recent campaigns of the TANs concerned with the three most popular issue areas: human rights, women's rights, and environmental rights. Significantly, the authors offer a number of definitions that, in comparison to earlier related literature, are quite broad. Thus, a TAN is described as any group having members from at least two different countries, where at least one of these is an international actor and where organization is motivated by mutually held principles and values.

\footnotetext{
${ }^{1}$ Grawemeyer Award, 1
} 
The book succinctly describes the patterns that characterize the interactions between TAN actors; the most successful and common of these being referred to as the "boomerang." In this particular pattern, domestic activists, unable to access or influence their national government, seek out an international ally who is able and willing to project their message in a compelling and effective manner to the international community. Actors from this broader community then attempt to use their leverage in order to petition the unresponsive national government to address the grievances of the domestic activists. Historically, boomerang patterns of activism have had varying success; the failure rate of transnational action network campaigns is high.

In fact, Tarrow finds that, in general, "transnational intervention fails more often than it succeeds.”2 Given this tendency towards negative campaign outcomes, the ability to identify the factors that determine variation in outcome is central to the development of a comprehensive theory. This is also a matter of potential interest to the network actors, as they stand to gain significantly from being able to assess, in advance of its initiation, the chances of success of any single campaign. As Keck and Sikkink note, the costs of organizing and acting on the transnational level are enormous so that, while the logic behind the formation of a transnational action network is likely of an altruistic nature, the activists that create them are prone to think strategically about their humanitarian efforts.

Keck and Sikkink, adopting an exploratory approach in order to identify the reasons for success or failure in a number of empirical cases, find that their dependent variable (campaign outcome) is determined by four independent variables.

The first of these concerns the characteristics of the state being targeted by the campaign. The authors expect success to be most likely when the targeted state is

\footnotetext{
${ }^{2}$ Tarrow, 2005, 200
} 
responsive to pressure. Lobbying from within the state is most likely to be effective in a democratic, rather than authoritarian, domestic context. External influence is most likely to achieve results when the targeted state's position in the international system makes it vulnerable. Various conditions might heighten vulnerability: if a state is party to international agreements, is seeking to maintain or increase its access to the international market, is seeking recognition as a democratic state, or generally stands to gain or lose economic opportunities as a consequence of its international reputation. The authors state "Vulnerability arises both from the availability of leverage and the target's sensitivity to leverage; if either is missing, a campaign may fail.”3

The second independent variable concerns the specific manner in which a campaign is cast; Keck and Sikkink write at length of the importance of strategic issue framing and resonance. A frame, or conceptual presentation, is most likely to succeed when it is presented in a manner that makes explicit that 1) there is a right and a wrong side between which the public must choose, 2) the problem is not naturally occurring, but rather a result of human action and intent 3) there is, consequently, someone who bears the blame for the creation of the problem and, 4) the stakes of campaign success are high, as in a life-or-death outcome for innocent victims. The frame is selected in order to achieve maximum issue resonance, meaning that the intended audience will experience empathy with the victims and a desire to engage personally with the campaign.

The third independent variable concerns the publics’ perception of the activists themselves. In order to be effective, the activists must be seen as truthful reporters and trustworthy messengers. The public must believe that activists are legitimate representatives of the victims; this is particularly important in those circumstances under

\footnotetext{
${ }^{3}$ Keck and Sikkink, 29
} 
which a first-world activist claims to act on behalf of a third-world victim. Relationships between activists must be transparent and unproblematic.

The final causal variable concerns the quality of the network itself. Keck and Sikkink emphasize that the size and the density of a network are directly related to its ability to conduct a successful campaign or bring pressure to bear on the targeted state. Size of a network simply refers to the number of members it claims. Density, a more complex concept, is the measure of the number, quality and strength of the ties that exist between network members. Such ties allow for smooth transfer of resources, coordination of action, information dissemination, and access to powerful potential allies. Size and density are related concepts in so far as changes in one measure can be expected to have an impact on the other.

That three of the four independent variables focus on the network and its campaign clearly indicates that Keck and Sikkink find outcome to be primarily dependent on campaign-level factors. The fourth independent variable concerns the vulnerability of the target to international-level actors that are in alliance with the TAN; the authors do not consider that these actors might work to oppose the TAN or to shield the target from TAN pressure. They also neglect to discuss whether networks can create an ally where there is none, or bolster it where it is insufficiently powerful vis-à-vis the target. Generally, Keck and Sikkink do not consider the complexity of the international scheme or its component parts. The reason for their intense focus on campaign-level factors can be found in the conclusion of their work wherein the authors discuss the ways in which their theory is distinct from Liberalism.

The authors acknowledge that both theoretical perspectives allow that individuals 
can act as the "motor of change," and enjoy a notable degree of influence on the national and international level. ${ }^{4}$ According to Keck and Sikkink, Liberalism holds that individuals structure the preferences of (democratic) states and, by extension, impact inter-state interaction. However, these individuals’ behaviors are informed by risk-averse self-interest, and not principles or values, and so cannot explain how individuals might influence other self-interested individual-level actors to adopt a position similar to their own. In essence, Liberalism holds that change occurs via a one-way vertical structure of influence and communication that links sub-state to state levels and state to international levels.

In contrast, theories of transnational network advocacy envision that horizontal contact is established between actors, frequently as a result of already-existing complimentary values. However, where similar values do not yet exist, a network can facilitate communication between actors; such exchanges have a constructivist effect on network participants that speeds the development of shared values. Essentially, the authors imagine that self-interest is necessarily tied to a specific context while certain values are potentially universal, located in the individual and rather than in a particular political or social context. Communicating these values to others can trigger mobilization around shared principles and, where a state resists actors’ attempts to influence its preferences from within then coordination between the network and a power-wielding ally on the international level can structure state preference from without.

It follows from this theoretical foundation that the character of the network is of utmost importance, since only a network can facilitate constructivist exchanges and then only under certain conditions. Of secondary importance is the character of the state;

\footnotetext{
${ }^{4}$ Keck and Sikkink, 213
} 
democracy allows for influence from within while the absence of democracy can lead to efforts to influence state preferences form without. Lagging far behind are network allies originating in the level of the international system. Their origins, characters, preferences remain a mystery. To a great degree, the authors leave to chance the probability that a network will secure international-level leverage that is both powerful and relevant enough to restructure the target's preferences and thereby consolidate change. 


\section{TRANSNATIONAL ACTIVISM IN ECUADOR: AN OVERVIEW}

In August of 2003, the Ecuadorian government announced the completion of the Oleoducto de Crudo Pesado [Heavy Crude Pipeline, or OCP], Ecuador’s second oiltransporting pipeline. The government, the project financiers and the oil industry praised its modern technological features that, they claimed, would minimize the pipeline's environmental and social impacts. A network of environmental and human rights activists from the international, national, regional and local arenas rejected this claim and assailed the government's decision to construct the OCP.

Such wildly contrasting claims are common to the debate over oil activity in Ecuador. Oil exploration and exploitation activities have grown steadily in scope and frequency since Texaco’s 1964 discovery of reserves in the eastern Amazon. Anti-oil activism began in the 1970s and increased in intensity and prevalence in the mid 1980s. Indigenous activism also began in the 1970s with the opposition by the Shuar nation to the oil industry’s presence on their traditional lands and, by the early 1990s, gained sufficient momentum to constitute a powerful, national-level social movement with a political wing. Given the 30-year history of oil industry and opposition in Ecuador, it is not premature to ask whether and how the state has adjusted its national environmental and social policies over time and in response to transnational activism.

Comparison of the policies that governed the construction of the country's two 
pipelines facilitates just such a longitudinal investigation. These two projects, sitting as brackets around three decades of oil activity in Ecuador, and were the products of very different policy environments. The first of these, the Sistema de Oleoducto TransEcuatoriano [Transecuadorian Pipeline System, or SOTE], was constructed in 1969. In every respect, the SOTE project is a prime example of decision-making in an unconstrained policy environment, in which policies were created and adopted in complete absence of governmental or citizen regulation and oversight. The design process and initial construction phases of the SOTE predated the passage of Ecuador's first national laws regulating petroleum activities. It also preceded the arrival of international human rights and environmental organizations to Ecuador, and the formation of their national counterparts. Not surprisingly, neither the pace of construction nor the methods and materials employed reflected then-current industry standards or technological capabilities. ${ }^{5}$ The SOTE project is the historical precursor of the second pipeline and its attendant policy environment, and serves as an example of the nature and impact of unconstrained state decision-making.

In contrast, the OCP was the subject of intense debate lasting more than one decade. Policy negotiations date to 1989 when oil companies holding new exploration and exploitation contracts in Ecuador suggested to the government that the SOTE would be incapable of transporting future increases in production. During the protracted debate, a multiplicity of actors voiced their positions within a formally democratic national context, as each sought to influence the policy environment that prevailed during the conception and construction of the OCP. A number of these actors collaborated to form an advocacy network that sought to mobilize international and domestic support for its

\footnotetext{
${ }^{5}$ Aguinda v Texaco, 1993.
} 
anti-OCP position.

The state also took an active and visible role in the debate, particularly during the five-year period between the planning and design phases and the completion of the OCP. In many ways, it would seem that the state broke with its traditional disregard for environmental dimensions of national development policy. For example, it adopted a number of new environmental policy norms, required Environmental Impact Assessments (EIAs) from OCP Consortium members, established monitoring mechanisms, and expanded the institutional framework in support of these new responsibilities. The state also modified its position on the indigenous question; in 1990, for example, the state transferred the legal title to more than 3 million acres of land in the Amazonian Basin to indigenous communities. ${ }^{6}$

The question is whether these individual policies were indicative of the broader environmental and social orientation of the state and if they were formulated in response and accordance to the demands of the TAN. The conclusion is that, despite a marked difference in the salience of environmental and social issues during the policy development stages in the two cases, the government ignored TAN demands by refusing to prioritize the environmental and social dimensions of the OCP project. Thus, the TAN did not influence the normative or policy positions of the state in regards to the OCP. Rather, the Ecuadorian state continued to circumvent the requirements of its own national laws, undermine the capacity of domestic institutional mechanisms for regulation and enforcement, discount its obligations under international agreements and dismiss the recommendations of international experts and activists. In short, the TAN was ineffective since its OCP campaign can be classified as a failure.

\footnotetext{
${ }^{6}$ Farah, 1
} 
Analysis of the effects of the policy environments surrounding the two projects will go forth in a loosely comparative fashion. Since the Ecuadorian case is intended to serve as a partial test of Keck and Sikkink’s theoretical approach and predictions, discussion on the theoretical and methodological shortcomings of Activists Beyond Borders will be interspersed with the presentation and analysis of empirical findings. The goal will be to show that the Ecuadorian case seriously challenges several central theoretical claims and methodological approaches of the literature, and to explore the reasons and potential remedies for this disjuncture between theory and empirical observation. 


\section{CASE ANALYSIS: Methods and Caveats}

The Ecuadorian case unfolds over a period of thirty years. With the benefit of substantial room to practice hindsight, it will readily become clear that SOTE policies caused alarming environmental degradation and dislocating social effects. Unfortunately, the results of state policies during the OCP era are less clear. This is primarily due to the simple fact that few years have elapsed since the completion of the OCP: environmental impact might be latent, and the research community has had little time to perform and publish environmental assessments of the project in its operational stage. Such asymmetry points to the need to account for time issues in the research design. Pierson finds that institutional change and maturation are not quick processes, where they occur at all. The appropriate time frame for evaluation is furthermore related to the measurement of effectiveness applied in evaluating the outcome.

Keck and Sikkink do not provide measurements for or definitions of effectiveness. Instead, they treat effectiveness as a fluid concept best specified on a percampaign basis and in relation to the goals of that campaign. Thus, the authors state that

Activists in advocacy networks are concerned with political effectiveness. Their definition of effectiveness often includes some policy change by 'target actors' such as governments, international financial institutions like the World Bank, or private actors like transnational corporations. ${ }^{7}$

\footnotetext{
${ }^{7}$ Keck and Sikkink, 23.
} 
Accordingly, effectiveness can be evaluated by simply determining whether a target has responded to a TAN campaign with some change in policy. The case of the Ecuadorian TAN indicates that the government and Texaco were targeted, but neither responded to activist demands (for sustainable pipeline construction or a moratorium) by systematically altering policy. By Keck and Sikkink’s criteria, three decades of TAN activism in Ecuador have been completely ineffective.

Some authors suggest that assessment of the effectiveness of an organization should be based not on the achievement of its goals but on the structure and strategy of the organization itself. Sowa et al. support this approach, suggesting that the management of a certain organization is key, that outcomes may be objective or perceptual or both, and that corresponding distinctions are needed in order to identify, operationalize and test the outcome. ${ }^{8}$ Laraia goes a step further to argue that the measure, the unit of analysis and the predicted effectiveness are interrelated; she presents a table (roughly reproduced here) that shows three possible approaches to these integrated elements:

$\begin{array}{llll}\text { Measure: } & \text { capacity } & \text { performance } & \text { achievement } \\ \text { Unit of Analysis: } & \text { structure } & \text { process } & \text { outcome } \\ \text { Predicting: } & \text { performance } & \text { achievement } & \text { survivability }\end{array}$

Thus, the measurement of effectiveness can change, so long as the unit of analysis, the predictive goal, and the unit of measurement vary correspondingly. ${ }^{9}$ This idea approaches a more realistic acknowledgment of complexity of TAN goals (targeted practices that are connected to other elements of societal ordering) and network structure (the multiplicity of actors, motivations, culture-specific practices, and funding sources)

\footnotetext{
${ }^{8}$ Sowa et al., 715,720 .

${ }^{9}$ Laraia, 758.
} 
than does the guideline offered by Keck and Sikkink.

Where policy change constitutes effectiveness, per Keck and Sikkink’s recommendation, the definitional scope depends on whether one most values a simple (revocable) policy change, institutionalization of a policy change (provisions for enforcement and funding), or a fundamental and general norm shift. The flexibility of Laraia’s conceptualization notwithstanding, one may well question the value of defining effectiveness as a shift in policy without distinguishing between policy formulation and implementation, and without specifying a time frame for assessing the degree of implementation. For example, Arsel questions whether the 'freezing' of the Akkuyu nuclear power plant proposal, which enjoyed the full support of the Turkish government, "qualifies the networks as a success story?"10 He concludes that it is "premature” to assume that a freeze of the proposal is equivalent to a long-term re-orientation on the part of the government, and states, generally, that policy shifts are "best interpreted as a shortterm strategic victory.”" ${ }^{\prime 1}$ In making this argument, Arsel puts forth an insightful observation about the significance of "negative versus affirmative” success, saying that,

The impact from the advocacy efforts may be time delayed. Negative success, the freezing of the Akkuyu project for instance, is often half the story. To sustain such a decision, major policy shifts need to take place and new alliances need to be made. $^{12}$

With this is counsel mind, it is reasonable to argue that, where policy outcome is to be the focus for evaluating TAN effectiveness, then effectiveness should be gauged by, at a minimum, the following standards: 1) in comparison to other theoretically possible results, 2) in terms of the durability of the result, as seen in efforts to enforce or

\footnotetext{
${ }^{10}$ Arsel, 2; 8.

${ }^{11}$ Arsel, 2; 8.

${ }^{12}$ Arsel, 8.
} 
institutionalize the achievement, and 3) in terms of the scope of the impact, i.e., whether its application is issue-specific or represents a fundamental norm shift.

Applying these criteria, it is clear that the OCP campaign failed to prevent the construction of the pipeline and had little or no impact on policies governing its design, construction, or operation. However, the campaign did cause the state to make small adjustments to its policies concerning the secondary environmental and social impacts of the pipeline; while these were issue-specific, they have thus far been enforced. On balance, the campaign was completely ineffective but the TAN can be credited with small achievements.

Where it is relevant, institutional change made during the 1970s is considered a completed process, while institutional adjustments made during the 1990s is regarded as provisional and inconclusive. It is also reasonable to expect that environmental and institutional lessons learned from the SOTE era might have been applied during the OCP era; a temporal analysis should ask whether and how institutional learning has occurred. For these reasons, it is appropriate to place greatest emphasis on the outcomes of the SOTE case: the environmental impacts that have been observed and an understanding of their origins and implications. Conversely, it is most reasonable to focus on policy development stages in the OCP case: design and siting of the pipeline, treatment of relevant scientific information and evidence of learning, and the influence of a democratic national context.

It is important, particularly since I will emphasize different aspects of the two projects, that some elements are held constant. To this end, both case study discussions will be structured by a focus on two categories: Actors and Institutional Capacity, and 
Social and Environmental Impact. The first category (Actors and Institutional Capacity) encompasses those factors most salient to the development of policy: who influenced the pipeline agenda and how; and, whether the state had, or attempted to establish, the capacity to manage social and environmental issues through legislation, monitoring, and enforcement. It is important to consider both the state's preferred procedural and normative position, and scrutinize its efforts to ensure sufficient institutional capacity in support of its stated goals.

The second category (Social and Environmental Impact) describes the direct and indirect outcomes of policy decisions. This is accomplished by asking: what impacts followed directly from the design and management of the pipelines; and what cumulative impacts are associated with the pipeline projects? In answering these questions, it is helpful to investigate the policy provisions for community consultation, physical design, construction processes, and siting decisions, monitoring mechanisms and emergency contingency plans. 


\section{CASE ANALYSIS:}

\section{Empirical Challenges}

Four features common to both pipeline project eras have complicated the state's role in and responsibility for environmental stewardship and minority rights provision. The first of these factors concerns the national political landscape. Prior to and during the SOTE period, a series of military governments and coup-based power transitions defined the makeup and nature of the state. Junta governments typically governed by decree, and tended to insulate the country from certain external influences, like non-governmental scientists and activists. Military governments predicated internal legitimacy on successful economic policies, which commonly translated into resource-intensive development schemes.

Democratic constitutional rule, reestablished in the 1980s, did little to restrain the armed forces or lengthen political time horizons. Presidential instability and the occasional disbanding of Congress and the Supreme Court have encouraged volatile policy shifts and created an inhospitable environment for institutional maturation. Not surprisingly, state agencies hold conflicting and frequently-shifting mandates for policy implementation, oversight and enforcement. These effects are compounded by a highly fragmented party system that results in frequent governmental gridlock. The short political timeframes common to all Ecuadorian politicians create incentives to prioritize short-term goals, like job creation, over those goals requiring sustained action and having latent outcomes, like environmental management. 
Second, national economic factors have contributed significant disincentives for and barriers to the prioritization of environmental management. Given the incentive to emphasize economic development and the lack of comparable alternative exports, it is not surprising that every government since the mid-1960s has designed its economic policies around the petroleum industry. Flores and Merrill note that, "Petroleum was the single most important element in the Ecuadorian economy, accounting for over 14 percent of the GDP in 1986, two-thirds of all export revenues in that year, and much of the foreign investment."13 The dominant position of petroleum within the national economy has gone unchallenged for four decades and, when placed in context of the requirements of external debt service, promises to be self-replicating. This factor has increased in importance over time, as a mushrooming external debt intensified the need to accumulate capital. As Watts notes: "During the 1980s, the pressure for debt service coupled with a neoliberal agenda imposed by a series of civilian governments placed further pressures on opening new oil concessions ...,14

Governmental decisions to carry out structural economic adjustments as required by lending terms of multilateral financial institutions have increased the volatility of domestic politics making it an unattractive political option; nevertheless, the state continues to bend to the will of its creditors. In short, economic reality has constrained policy options, encouraged uneven institutional development, and predisposed the government to act in favor of development projects, particularly within the energy sector of the economy.

The third significant challenge to the state's capacity for environmental

\footnotetext{
${ }^{13}$ Flores and Merrill, 1.

${ }^{14}$ Watts, 2.
} 
stewardship is Ecuador's physical landscape. The country is divided into four verticallyarranged regions that have distinct climates, seasonal variations and cycles, and temperatures. Mainland pipeline routes necessarily transverse the three continental regions: the Amazon, the Sierra and the Coast. The geographical and climatic variation along a single pipeline route is problematic for pipeline siting, construction and maintenance. For example, the timing of the rainy season varies by region: October-April for the Sierra; January-April for the Coast; year-round in the Amazon. Nevertheless, all regions are vulnerable to flooding and mud- and landslides, events that threaten pipeline integrity. Pipeline design must account for variation within and between the regions.

Oil reserves are primarily located within the Amazon Basin of the Sucumbíos province in the Oriente, or eastern portion of the country constituting one half of Ecuador's total geographic area. ${ }^{15}$ This region maintains an equatorial climate, meaning that is notable for its precipitation rates and high temperatures. Ports and refineries are located along the western coast. The coast is a sub-tropical environment that is vulnerable to large-scale climatic influences that originate with oceanic currents, like the Peruvian Current and El Niño. ${ }^{16}$

The Oriente's reserves are separated from western coastal ports by the Sierra, or Andean Cordillera, a north-south mountain range with a peak altitude of 6,267 meters (20,560 feet) above sea level. In the Andes, climate, river currents, and temperature vary with altitude. The Andean snow pack gives rise to several major river systems. German scientist Alexander Von Humboldt coined the term 'Volcano Alley' in reference to the

\footnotetext{
${ }^{15}$ Martin, 70.

${ }^{16}$ WHO: El Niño.
} 
portion of the Inter-Andean valley that is lined by thirty-three volcanoes. ${ }^{17}$ Of these, nine volcanoes are classified as active, and Cotopaxi is recognized as the world's highest active volcano. Beginning with a significant eruption in November of 2002, El Reventador entered a phase of volcanic activity "generally shifting from effusive towards explosive;” the more active Guagua Pichincha erupted in 1981, 1982, 1997, 1998, 1999, 2000, 2002 and 2004. ${ }^{18}$ Lahar flows (mixtures of ash, rock, lava and water) are common both in conjunction with and independent of volcanic eruptions, and seismic activity occurs daily along Ecuador's thousands of fault lines. ${ }^{19}$

Because Ecuador is one of the world's most 'mega-diverse' countries, the environmental stakes are high and there is little room for error. According to the President of Ecuador's Advisory Commission on Environmental Means: “Ecuador has twice the plant and animal species of the United States and Canada together, four times more than all of Europe, and the largest number of plant species per unit of area in the Americas." ${ }^{20}$ Ecuador claims some 1,600 bird species in total; the Mindo Nambillo Cloudforest Reserve alone houses more than 450 species of birds, of which 46 are close to extinction. ${ }^{21}$ EarthTrend's application of the Protected Area Management Categories, as developed by The World Conservation Union, reveals that, in 2003, Ecuador had 12\% of its total land area under Categories I and II protection (for scientific, wilderness and ecosystem protection, and conservation of specific natural features). ${ }^{22}$ Of the total national land area, $26 \%$ is under some degree of protection. ${ }^{23}$

\footnotetext{
${ }^{17}$ MREE, 1.

${ }^{18}$ Smithsonian Institute, 1.

${ }^{19}$ Yánez, 1.

${ }^{20}$ Luis Carrera de la Torre, 1.

${ }^{21}$ Amazon Watch, 2003, 3.

${ }^{22}$ EarthTrend, 1.

${ }^{23}$ EarthTrend, 1.
} 
Finally, Ecuador is also distinguished in the diversity of its social landscape. Although some estimates vary drastically, indigenous people are commonly thought to number 4.5 million, or about 45 percent of the national population. ${ }^{24}$ This segment of the population is further divisible by particular ethnic identity; there are at least twelve nations, each with its own language, culture and history. ${ }^{25}$ The vast majority of the indigenous population lives in the Sierra, or mountainous regions, and was integrated with the national culture and economy through feudalistic land tenure arrangements that prevailed until the 1964 Agrarian Land Reform. While this reform was sweeping, it lacked the institutional backing to be effectively implemented. An immediate result was that the Sierra indigenous population that lacked the resources needed to acquire land in the highlands.

A second and related legacy of the agrarian reform was the rush of dislocated migrants from the Sierra to the Amazonian region. The government facilitated this relocation by declaring agriculturally unproductive land abandoned, and granting land titles to any person who made Aproductive use of at least $80 \%$ of a holding. ${ }^{, 26}$ Many large landowners, fearing expropriation of their lands under the 1964 reform, sold off large amounts of (poor quality) land and headed to the Oriente, where the government's incentive package for colonizers included funding and protection for new landowners. For example, one report mentions that, “ . . colonists normally received a forty- to fiftyhectare parcel in contrast to the minifundio typically awarded former sharecroppers or huasipungueros. ${ }^{27}$

\footnotetext{
${ }^{24}$ Martin, 70.

${ }^{25}$ Delgado.

${ }^{26}$ IACHR, Footnote 30.

${ }^{27}$ Coutsoukis, Ecuador: Social Classes - Peasants.
} 
Barraclough and Eguren note that the Ecuadorian Agrarian Reform and Colonization Institute (IERAC) “assigned over 2.5 million hectares of "vacant” state lands, mostly in the Amazonian forest region, to some 60,000 colonists” in the two decades following the reform. ${ }^{28}$ An estimated 250,000 to 300,000 colonizers lived in the Oriente by $1997 .{ }^{29}$ This planned colonization of the Oriente misappropriated lands traditionally occupied by a variety of uncontacted ethnic groups. The state's promotion of colonization of the Oriente continued ever after it ratified the International Labor Organization (ILO) Convention No. 169 which states that "The rights of ownership and possession of [indigenous peoples] over the lands which they traditionally occupy shall be recognised." ${ }^{30}$

Amazonian indigenous nations that historically had enjoyed a high degree of autonomy from the national government and economy organized against the invasion of industry and colonizers. The Federation of Shuar Centers was founded as a local activist group in the Amazon Basin in 1964, while highlanders established a regional indigenous organization, ECUARUNARI, in 1972. As oil extraction activities spread, CONFENAIE was established in 1980 as a regional body representing the interests of 500,000 indigenous Amazonians (Wilkenfeld). Each of these groups demanded that the government redistribute appropriated land according to historical and cultural basis of ownership. As Kimerling notes, "Legalization and demarcation of indigenous territories has long been the frontline of defence used by indigenous organizations to protect indigenous peoples from the oil boom. ${ }^{\text {} 31}$ Thus, in a single decade and in the absence of

\footnotetext{
${ }^{28}$ Barraclough and Eguran, 233.

${ }^{29}$ IACHR, Chapter IX: Section 4.

${ }^{30}$ International Labor Orgnization, Conventin No. 169.

${ }^{31}$ Kimerling, 1996, 68.
} 
any precedent, the opening of the Oriente sparked a movement in support of ethnicallybased land rights and the creation of two strong regional organizations.

The land issue gained salience during the OCP era as the increasing strength of the indigenous movement forced the government to confront the issue. In 1981, the state passed La Ley Forestal y de Conservación de Áreas Naturales y Vida Silvestre [Law of Forestry and Conservation of Natural Areas and Wildlife]. This legislation focused exclusively on the Oriente, claiming subsurface soil rights for the state. In 1986, the regional organizations ECUARUNARI and CONFENAIE united to form CONAIE. This organization's first national demonstrations were organized in protest to governmental land reform proposals in 1990 and again in $1994 .{ }^{32}$ Indeed, CONAIE that has consistently made "integral agrarian reform one its key demands" is made clear by the inclusion of land titling at the top of its list of demands during the 1990 uprising and by the government's descision to respond to the 1990 strike by dispatching IERAC officials to negotiate with the leadership of CONAIE. ${ }^{33}$ However, while these uprisings did force proposal modifications resulting in increased protection for communal territory integrity and in the transfer of legal title to three million acres of traditional lands to the Organization of Indigenous Peoples of Pastaza (OPIP), they did little to systematically improve the status of indigenous land rights. ${ }^{34}$ The 1995 establishment of CONAIE's political arm, Pachakutik, resulted in the reintroduction of the land issue onto the national political agenda while the on-going legal and physical oil-related conflicts in the Oriente have earned Ecuadorian land issues a place on the international agenda.

\footnotetext{
${ }^{32}$ Andolina, 1994.

${ }^{33}$ IWGIA, 165; CONAIE, Sixteen Demands; Martin, 57.

${ }^{34}$ Matin, 57.
} 
CASE: SOTE ERA, 1964 - 1990

\section{Actors and Institutional Capacity.}

In 1964, Texpet, a subsidiary of Texaco-Petroleum Company, concluded the first successful oil exploration in Ecuador's Amazon rainforest. The following year, a Joint Operating Agreement known as the ‘Napo Agreement’ established Texaco’s sole responsibility for the construction and operation of all facilities and infrastructure necessary for oil exploitation and transportation until 1990, at which time the state would have the option of assuming control of the consortium. In 1969, the government and the Texpet Consortium agreed to construct the SOTE. The pipeline’s 480-km route originated in concession areas in the north-eastern Amazon and terminated at Esmeralda's oil refinery and ports on the western coast. It was the world's highest pipeline, peaking at 4,064 meters above sea level as it crosses the Andes. ${ }^{35}$ The SOTE was initially designed to carry as many as 250,000 barrels per day of high-value light crude. $^{36}$

The military government of General Lara implemented the country’s first petroleum law after SOTE construction commenced. La Ley de Hidrocarburos de 1971 [Hydrocarbon Law of 1971] required that oil companies take those measures necessary for the protection of the "flora and fauna," and prohibited the burning of natural gas

\footnotetext{
${ }^{35}$ Energy Solutions, 1.

${ }^{36}$ Encyclopedia of Nations, 2006.
} 
without governmental permission. ${ }^{37}$ Article 29 of the law established that: "Contractors are obligated to: (e) employ modern and efficient machinery; (s) adopt necessary methods to protect plants, animals, and other natural resources ; $(\mathrm{t})$ avoid contamination of waters, air and lands. ${ }^{\text {,38 }}$ These obligations were reiterated, but not further specified, in the Hydrocarbon Laws of 1974 and 1978 and the Hydrocarbon Law Reform of 1982.

In 1972, the Texpet consortium completed the construction of the SOTE. During the same year, the state negotiated the Contrato para exploración y explotación de hidrocarburos entre Texaco Petroleum Company y Ecuadorian Gulf Oil Company [Contract between the Texaco Petroleum Company and the Ecuadorian Gulf Company for the exploration and exploitation of hydrocarbons]. Powers and Quarles find that, "the language in the contract reflects the prohibitions included in the [1971 Hydrocarbon] law.”39 Finally, in 1973, Gustavo Jarrín Ampudia, Minister of Natural Resources, entered Ecuador into the Organization of Petroleum Exporting Countries (OPEC) and renegotiated governmental contracts with private foreign oil companies, extending them until June of 1992.

Thus, the SOTE was conceived of and partially constructed before the creation of legal and institutional mechanisms providing for governmental control of the hydrocarbon industry, and it was completed before Ecuador committed to any international production standards. Furthermore, state policies, where they existed, centralized legislative and regulatory functions under the executive. General Lara facilitated this concentration of power by creating a national oil company, the Corporación Estatal Petrolera Ecuatoriana [Ecuadorian State Petroleum Corporation, or

\footnotetext{
${ }^{37}$ Kimerling, 1991, 19.

${ }^{38}$ Powers and Quarles, I, author's translation.

${ }^{39}$ Powers and Quarles, I.
} 
CEPE], in 1972. The CEPE gained a 62\% majority interest ownership of the Consortium in 1976, and in 1986 the company became the sole owner of the Transecuadorian pipeline in 1986.

The state preference for centralization of legislative and oversight functions was also evident in the design of a new agency, the Dirección General de Medio Ambiente [General Directorate of the Environment, or DIGEMA]. This executive-branch agency was established in1984 under the auspices and control of the Ministerio de Energía y Minas [Ministry of Energy and Mines, or MEM]. The inherent conflict of interest and the potential for the subordination of DIGEMA's environmental mission are clear when one considers the MEM's primary mission: to promote and facilitate extractive industry.

\section{Social and Environmental Impact.}

Spills caused by breaks in the pipelines have resulted in extensive environmental damage in Ecuador. Physical compromise of the SOTE has resulted primarily from poor planning for and response to natural disasters, and from substandard or nonextant maintenance.

The potential for environmental disaster caused by the state decision to route the SOTE through areas known for volcanic and seismic volatility was not accounted for through pipeline design or emergency contingency planning. Two 1987 earthquakes (magnitudes 6.1 and 6.9) occurred "along the SOTE alignment" in the area of volcanic activity known as Quito/Reventador. ${ }^{40}$ Slope and river dam failures and massive landslides destroyed seventy kilometers of the SOTE, resulting in plummeting production

\footnotetext{
${ }^{40}$ Veldman, 1.
} 
rates and a five-month repair and cleanup effort. As there were no disaster response plans in place, the cleanup effort was coordinated and financed by the World Bank through its Emergency Petroleum Reconstruction Project. ${ }^{41}$ This was "the most extensive naturally induced pipeline outage ever experienced in the world." ${ }^{, 2}$ The duration of the outage reflects the lack of contingency planning and the necessarily improvised nature of remediation efforts.

One year later, the SOTE ruptured during a landslide near Esmeraldas, the destination port. Unfarallon reports that, "Oil flowed down the streets of the town and into the river. Around $10 \mathrm{pm}$, a spark ignited the oil. Twelve people died from the flames, six more were never found., ${ }^{43}$ A SOTE rupture in August 1992 spilled 275,000-gallons, “caused the Rio Napo to run black for days, and forced downstream Peru and Brazil to declare national states of emergency for the affected regions.”44

Unfarallan reports that in the first two decades of operation, the SOTE sustained "more than 60 major ruptures resulting in 614,000 barrels of spilled oil B more than twice the 260,000 barrels that were spilled by the Exxon Valdez." ${ }^{45}$ Knudson notes that, "By contrast, the 800-mile trans-Alaskan pipeline, which came on line in 1977 and carries more than twice as much oil, has spilled just 85,000 barrels. ${ }^{46}$ The Organization of American States added that Aruptures of secondary pipelines have resulted in substantial additional discharge into the environment. An additional 1,000 to 2,000 gallons of oil reportedly spill from the flowlines connecting the wells to the stations every two

\footnotetext{
${ }^{41}$ Babelon and Dahan, 10.

${ }^{42}$ Veldman, 2.

${ }^{43}$ Unfarallon, Oil and Ecuador.

${ }^{44}$ Butler, 1.

${ }^{45}$ Unfarallon, Oil and Ecuador.

${ }^{46}$ Knudson, 2.
} 
weeks."47

State siting decisions also left the SOTE vulnerable to guerillas that operate in the Oriente. Human activity has frequently undermined the physical integrity of the SOTE, resulting in oil spillage. In acts of sabotage and anti-oil protest, the SOTE has been attacked and bombed. The steady increase in militarization along the pipeline route is evident. The government responded to oil-related strikes and protests in the Sucumbios, Napo and Orellana provinces by declaring numerous states of emergency, some lasting as long as two months. ${ }^{48}$ Rene Bucaram, former director of Texaco’s Ecuador operations, accused the state-run CEPE of capitalizing on the instances of human sabotage to divert attention from the true causes of SOTE spills. After the 2001 "River Toachi” spill, he told Reuters: “They aren't going to keep tricking us that this was caused by a bomb. This is poor management of the pipeline, and it's time the government provides an explanation."49

Increasingly, paramilitary groups such as the Revolutionary Armed Forces of Ecuador (FARE) have claimed responsibility for attacks. The FARE is modeled on and articulated with Colombia's Revolutionary Armed Forces of Colombia (FARC), and its presence in Ecuador underscores fears that the spillover of Colombia's civil war into the northeastern provinces of Ecuador translates into intensifying security threats to Ecuador’s pipelines. Amazon Watch notes that, “In the past 12 years, Colombia’s Caño Limon oil pipeline has been attacked more than 700 times by guerrilla groups, spilling more than two million barrels of crude oil. Five attacks on Ecuador's SOTE have already

\footnotetext{
${ }^{47}$ IACHR, Chapter VIII, Section 2.

${ }^{48}$ US Department of State, 1.

${ }^{49}$ Reuters, 1.
} 
left several people dead. ${ }^{, 50}$ Thus, while the siting of the pipeline in the northeastern provinces of Ecuador increased the possibility of significant, negative environmental impact resulting from local insurgency, state policy has been strictly retroactive.

Most of what is known about the impact of oil operations in the Amazon during the first two decades has been collected, analyzed and distributed by individuals working through extra-governmental forums. Judith Kimerling's study of the environmental and social impacts of oil activities in the Ecuadorian Amazon was the first critical documentation and assessment ever made public; it appeared in English in 1991 and then in Spanish in 1993. This pioneering work "elevated oil contamination in Ecuador to the status of an international environmental problem. It was the first time that clear evidence was presented to the media, the government, and the oil companies, that supported the

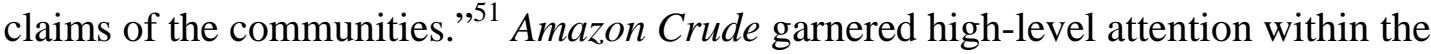
NGO community, which reacted quickly by publicizing the information gathered by Kimerling. The Natural Resources Defense Council (NRDC) led the pack by publishing the 1991 English version. Robert F Kennedy, Jr., then staff counsel for the NRDC, wrote a preface that promised plenty of facts:

Discharges from secondary pipelines have never been estimated or recorded; however, the smaller flowlines discharge approximately 10,000 gallons per week of petroleum into the Amazon, and each day production pits dump an astounding 4.3 million gallons of toxic production wastes and treatment chemicals into Amazonia's rivers, streams and groundwater. ${ }^{52}$

In addition to quantifying the direct environmental damage, Kimerling's narrative contributed to an understanding of the cumulative impacts of the oil industry in Ecuador by describing the process from cradle-to-grave. For example, she noted that petroleum

\footnotetext{
${ }^{50}$ AmazonWatch, Eostar 2002, 1.

${ }^{51}$ San Sebastián and Córdoba, 7.

${ }^{52}$ Robert Kennedy Jr., Preface.
} 
companies constructed many roads into the Amazon in order to facilitate access to the concession areas and import construction equipment to build exploitation facilities. This caused mass deforestation, threatened endangered species, and disrupted ecosystems. Kimerling also documented the leeching and dumping of toxic byproducts, and traced the effects of these practices on the health of the Oriente's indigenous inhabitants. Kimerling made clear that these peoples depended on the freshwater Amazonian river system for bathing, cooking, and drinking and food cultivation purposes and looked to the rainforest in general for medicine, education, sustenance, shelter, cultural customs and spiritual identities.

A second wave of environmental impact assessment was generated in the course of on-going, class-action civil suits against Texaco and other petroleum companies. Aguinda v Texaco, brought on behalf of indigenous Amazonian inhabitants against Texaco, was filed by an Ecuadorian expatriate lawyer in the New York court system in 1993 under the provision of the US Alien Claims Tort Act. The fact-finding missions mandated by this and by subsequent trials have reduced scientific uncertainty about the environmental effects of certain industry procedures. They have also affirmed the links between environmental degradation and pollution and the destruction of the habitats, culture, livelihoods and physical wellbeing of the Amazonian indigenous population.

Fact-finding in Aguinda v Texaco has primarily focused on Texaco’s operations policies in three areas of activity: exploration, exploitation, and infrastructure. Exploration phases rely on seismic testing, remote sensing and satellite imagery and mapping to detect the presence of oil reserves. This process requires that land is cleared to allow for the positioning of seismic testing devices. If the analysis looks promising, 
access roads to test well sites are constructed. The road construction is extensive and extremely invasive; as O’Rourke and Connolly explain, “mobile rigs for temporary drilling can weigh over 2 million pounds” and the effort to gain access means that substantially “clearing land for roads and platforms can lead to deforestation and erosion., 53

The second activity area, exploitation, is a two-part process. First, the extraction of crude from the ground relies on heavy machinery for the construction and operation of pumping stations. Then, the separation of the crude's constituent elements requires the use of toxic chemicals, including benzene, toluene, xylene, mercury, and lead. In its 20year operation in Ecuador, Texaco routinely dumped the formation waters (totaling 464,766,540 barrels) into open and unlined pits and nearby tributaries, and burned (or “flared”) an estimated 235 billion cubic feet of natural gas byproduct. ${ }^{54}$ Aguinda $v$ Texaco charges that Texaco’s production pits released “ 4.3 million gallons of toxic waste and treated chemical” into the environment. ${ }^{55}$

The third area of activity scrutinized by Aguinda $v$ Texaco is infrastructure construction. This broad category of activity includes the construction of access roadways; extraction, pumping, heating and transfer stations; central and secondary pipelines; 340 wells and 1000 pits; hard-waste dumps; helicopter landing strips; worker housing; and company towns. Infrastructure was often poorly designed and maintained. For example, Texaco spread crude waste on roadways, purportedly to decrease the amount of air-borne dust resulting from deforestation and construction of access roads. ${ }^{56}$

\footnotetext{
53 O’Rourke and Connolly, 594.

${ }^{54}$ Aguinda v Texaco, 5, 7.

55 Aguinda v Texaco, 20.

${ }^{56}$ Aguinda V Texaco, 16.
} 
Conventional wisdom holds that access roads, such as those constructed by the oil companies, open areas to "colonizers, land speculators and loggers ...,"57

Comparative research by Powers and Quarles indicates that: “Chevron’s decision to discharge saline produced water to surface waters in Ecuador was made at a time when these same discharges would have not have been allowed in U.S. oilfields in similar situations exactly because it was known that such discharges would have severely harmful impacts on the environment and human health. ${ }^{, 58}$ Thus, Power and Quarles find that, in its decision relating to discharge of production water, its design of waste pits, and its use of production water flaring, Texaco violated industry and international standards based on an scientific consensus regarding the environmental impacts of such practices.

Texaco states that it has "always worked with the technology that was consistent with generally accepted international standards at the time it operated the fields in Ecuador. The technology used by Texaco Petroleum Company was common in several other tropical or semi-tropical countries such as Angola, Brazil, Colombia, Indonesia, Mexico, and Nigeria." ${ }^{59}$ However, Aguinda v Texaco challenges such assertions by stating that, although Texaco had "obtained in 1971 and in 1974 patents in the U.S. on technological improvements for the reinjection of formation waters," it chose to employ outdated and discredited methods for handling formation waters in Ecuador. ${ }^{60}$ Thus, it is obvious that Texaco's decision to not employ then-modern technology in its operation in Ecuador was taken on a political, rather than a technological, basis. The lack of specification of contractor obligations in Ecuador's legislative mechanisms, and non-

\footnotetext{
${ }^{57}$ IACHR, 1.

${ }^{58}$ Powers and Quarles, I.

${ }^{59}$ Texaco, Press Release, October 2003.

${ }^{60}$ Aguinda v Texaco, 4.
} 
extant regulation and enforcement of standards allowed the industry to prioritize the economic over the environmental bottom-line.

Environmental damages have also been evaluated through proxy measures. For example, negative impacts of substandard operating procedures on public environmental services have been linked to public health threats. Epidemiologist Miguel San Sebastian established that proximity and exposure to oil wells, contaminated groundwater and dumping sites causes significant increase in the incidence of miscarriage, cancer, skin infection and respiratory illness. San Sebastian and Córdoba also demonstrated that the concentration of incidences in the Oriente has resulted from degraded environmental services rather than a natural predisposition of local indigenous persons. ${ }^{61}$

San Sebastian's findings indicate that the costs of the oil industry activity are not evenly distributed, but rather are borne primarily by the inhabitants of the Oriente including colonizers and indigenous people. While both of these groups have objected to their poor treatment by the government and industry, indigenous protesters have enjoyed a notably greater amount of publicity and support for their claims. Their ethnicity-based proprietary claims to ancestral lands and to inherited cultural practices, including those linked to life in the rainforest, resonated with environmental organizations working in Ecuador. The latter recognized that an alliance with the former could put a human face on the campaign, or to frame it in terms of the violation of the basic human rights of the affected indigenous populations. In doing so, the international activists protesting Ecuador's oil activities joined with the domestic indigenous-rights activists, facilitating an emerging network and shaping its character, content and organizational qualities.

${ }^{61}$ San Sebastian and Córdoba, 11. 


\section{Analysis.}

This case establishes a bottom line for comparison; it is a portrait of the social and environmental outcomes of unconstrained state decision-making. The SOTE era can also be said to contain the seeds of subsequent activism by providing a value-based motivation and a principal strategy for organized resistance. The network emphasized its opposition to the state's view of nature (specifically, the Amazon rainforest) as a space to be colonized, developed and subordinated to the national purpose. It also established that indigenous and environmental activists shared compatible values and goals.

Activism gained momentum as information about the SOTE’s social and ecological impact was gathered and disseminated. For example, San Sebastian and Córdoba explain that

In 1994 the Amazon Defense Front (Frente de Defensa de la Amazonía [FDA]) was created with the participation of numerous organizations of farmers and Indians and local non-governmental organizations (NGOs) with the objective of supervising the trial against Texaco. Since its formation, the group has organized various workshops about the environment, published accusations and reports about oil spills, led community information sessions and organized the visits of government representatives to the contaminated areas, in an attempt to open the eyes of the authorities to this disaster. ${ }^{62}$

In its earliest stages, the campaign consistently leveraged information to galvanize public support. Interestingly, the state often relied on the information supplied by activists since it lacked the institutional and technological capacities and expertise to make independent assessments. Certainly, the state was not able to counter the activists' claims and largely left this fight to the oil industry. The retraction of the state and concomitant dominance of industry in the fight over information seems to have

\footnotetext{
${ }^{62}$ San Sebastian and Córdoba, 8.
} 
contributed to "venue shopping," as in the filing of Aguinda v Texaco in the US court system.

Also important was information, such as that provided by San Sebastian, which pointed to a link between environmental and social damages. This connection facilitated a tentative alliance between environmental and indigenous activists, with the latter group drawing additional support from the international human rights movement. While symbiotic views on nature explain the normative basis for the interaction of these groups, the glue for their emerging alliance seems to have been tactical and pragmatic in nature. Engaging in what Keck and Sikkink refer to as “issue framing,” the alliance presented the environmentalists the opportunity to personalize the environmental problems by transferring the campaign focus from tree and plant species to innocent human victims. Symbolic strategies also supported this crucial step towards designing a campaign capable of attracting large and sympathetic audiences. It facilitated the network's goal of casting the problem in dichotomous (right or wrong) terms and establishing "short causal links.”63

Establishing that the object or action under protest was the creation, and remains the responsibility, of the targeted actor involves vilification of the target. The Ecuadorian case shows that, in the process of, establishing blame and responsibility, a network might too quickly dismiss the state's defense of its actions. Yet this is a factor to be accounted for in theoretical terms, at the least, since it may constitute a sufficient counter-argument and thereby impact campaigners' ability to monopolize value-based positions and to mobilize support.

The Ecuadorian state's support of the oil industry can not be readily dispensed

\footnotetext{
${ }^{63}$ Keck and Sikkink, 121.
} 
with in this analysis. That the government has steadfastly supported and promoted the oil industry is not surprising given that oil revenues account for a lion's share of the GDP. In defense of its promotion of extractive industry, the government has emphasized the importance of oil revenues to national economic well-being, and coupled this fact with a reminder that some $70 \%$ of the total national population lives under the poverty line. As Lucas reports, "Ecuadorian President Gustavo Noboa has repeatedly accused the conservationists of obstructing a project that is essential to reviving the troubled economy of this Andean nation of 12.4 million, which depends on oil for over one-third of export revenues. ${ }^{, 64}$ Essentially, the state has argued that it is obligated to guard against any forces that would undermine national well-being, uniquely situated to do so. This implies that the state faces a choice between providing for the benefit of the whole versus the benefit of the few, and that it must choose according to its moral obligation to the majority.

This contention is difficult to counter for those who would hold the government to international normative standards since exactly such a 'collective good' argument is enshrined as a fundamental principle in international law. However, the network could have seized the opportunity to question the state's attempt to define the national interest in economic terms. For example, the campaign could have asked how the state's corporatist mentality would serve other collective goods such as participatory democracy, civil liberties, or improved public services.

It would seem from Arsel's account of nuclear energy activism in Turkey that this particular counter-defense, one that claims that the state's policies are moral and in the public interest, will serve any number of governments quite well. This remains a

\footnotetext{
${ }^{64}$ Lucas, 1.
} 
profound problem, one yet to be clarified by the literature: how does, or should, a TAN prioritize the rights of the few over the rights of the many? Or, how does a TAN prioritize some collective goods over others, and can it expect to win popular support if it emphasizes clean air at the expense of employment and income opportunities? Realworld situations are not often simple, yet a TAN must, according to Keck and Sikkink, present to its public a right/wrong interpretation and a unified network position in order to create an effective frame. This is a major theoretical complication yet to be addressed by the proponents of the TAN perspective.

Finally, this case both confirms and challenges a number of theoretical assumptions about the political characteristics of the state. For example, it underscores that neither democracy nor formal provision of citizen rights guarantees that a state will be responsive to internal pressure. This is to be expected under Keck and Sikkink's formulation which holds that some degree of blockage of domestic political channels drives domestic actors to reach out to vertical and horizontal allies. The quality of democracy present within any given state can therefore be expected to affect the number and type of venues available to citizens who seek redress of grievances; this in turn is directly related to the need for a domestic activist or victim to seek international allies in order to exercise influence on the domestic government. However, one may object that simply describing a channel as 'blocked' is insufficient; degree of inaccessibility to, or repression by, the state would seem to matter for understanding both the motivation and the ability to actively organize. A similar line of argument is explored in the collective action literature by Mara Loveman who holds that, contrary to popular wisdom, "comparative analysis of the emergence of human rights organizations under military 
dictatorships in Chile, Uruguay, and Argentina” have shown that severe repression might catalyze collective action. ${ }^{65}$

The Ecuadorian case also makes clear that active membership in the international community of democracies does not always motivate a target to honor its international commitments or to react to an international “shame game.” In fact, despite mounting pressure from within and without, the Ecuadorian state quickened the pace of development of the Amazon, auctioning concession areas in violation of ILO No 169, and openly resorted to the application of force in order to repress network opposition.

International condemnation grew as the government repeatedly took extreme and illegal action in defense of the extractive industry. For example, its military signed contracts with private oil companies ensuring protection of personnel, equipment and production activities in exchange for meals and medical care. ${ }^{66}$ Indigenous inhabitants protested this militarization of their traditional and titled lands, but to no avail. Therefore, the contractual military-industrial relationship violated Article 28 of the United Nations Draft Declaration of the Rights of Indigenous Groups, which states that "Military activities shall not take place in the lands and territories of indigenous peoples, unless otherwise freely agreed upon by the peoples concerned.»67

Amnesty International reported numerous instances in which indigenous peoples have suffered bodily harm, kidnappings, torture and death as a result of military action on their lands. ${ }^{68}$ The Inter-American Court of Human Rights reprimanded the government for its role in these developments, and charged it to take corrective action immediately.

\footnotetext{
65 Mara Loveman, 477.

${ }^{66}$ Beltran and Oldham, 1; Martin, 59.

${ }^{67}$ United Nations, 1994.

${ }^{68}$ Amnesty International, Annual Report, 2005.
} 
However, Amnesty International reported that Ecuador’s Minister of Mines and Energy responded to the injunction by saying "la OEA no manda aquí" [or, "the OAS does not give the orders here"] and affirming that the state's policies would remain unchanged. ${ }^{69}$ Attempts to "shame" the state were not effective leverage tools. Ongoing monitoring and reporting by the international normative community did not result in hard consequences for the Ecuadorian government's repeated violation of its commitments to international human rights norms. International obligations did not cause the state to be responsive to external criticism of its human rights or environmental policies and practices. The state cannot be said to have shown any appreciable degree of vulnerability to international shaming, or what Keck and Sikkink refer to as "moral leverage.,"70

How then should activists assess the potential for moral leverage over the target? How, for example, can one judge the degree to which a state is likely to value, or otherwise be sensitive to, international opinion? What should be made of the fact that the majority of states targeted by TANs at any given moment do, in fact, maintain an array of economic and diplomatic relations with other international actors? Clearly, some differentiation between types of commitments, coupled with a contextual understanding of a targeted state's international and domestic position, is required.

Furthermore, the international system is not a static entity and changes abroad may alter the availability of leverage; this could be problematic for sustained campaigns. Pieck finds that this was a complicating factor in the case of Ecuador, since "the landscape of opportunities that many indigenous leaders and environmental NGOs

\footnotetext{
${ }^{69}$ Amnesty International, Death Threats/Fear for Safety, 2004

${ }^{70}$ Keck and Sikkink, 23.
} 
encountered in the late 1980s and early 1990s had changed by 2005.”71 How can activists predict, much less control, the moment at which international conditions might complement domestic events to increase state sensitivity and thereby yield the desired campaign outcome? Sikkink herself acknowledges the difficulty inherent in this exercise which requires that activists visualize simultaneous political opportunities at both the domestic and international levels. She warns against the temptation to focus on the opportunity structure at one level while holding the other level constant, and should instead view their environment as “a two-level interacting political opportunity structure."72

This point is further illustrated by Sydney Tarrow, whose The New Transnational Activism describes the events that led to Pinochet's 2004 indictment for human rights crimes. Chilean exiles collaborated with British and Spanish authorities, rather than the reluctant Chilean state, to arrange for Pinochet's first interrogation in Spanish courts. The 2004 ruling against Pinochet eventually encouraged the Chilean state to reverse policy and pursue the prosecution of a number of junta leaders, producing what Tarrow refers to as a domestic "justice cascade."73 However, the author contends that this outcome resulted from the serendipitous, rather than strategic, combination of a number of delicate, time-sensitive and complex international and domestic events. As emphasized by Tarrow: “international opportunities seldom come together as fortuitously as they did in the Pinochet case."74

What is clear with regards to this matter is that greater specification of terms and

\footnotetext{
${ }^{71}$ Pieck, 311.

72 Sikkink, 2005: 158-9.

73 Tarrow, 2005: 143.

74 Tarrow, 2005: 144.
} 
conditions is needed. As the Ecuadorian case suggests, it is unwise to anticipate state decision-making based on, for example, the classification of a target state as "democratic or not.” Static conceptions, presented without referents, are not theoretically meaningful to the scholar or practically useful to the activist. It is a generally accepted notion that the term "democratic" can refer to any number of policy constellations, as the political science literature concerned with subtypes and adjectivization of democracy well illustrates. Furthermore, a democratic state, however specified, should not be expected to function as a uniformly democratic entity. Rather, all states display gradations of democratic tendencies that vary according to any number of factors, including: the nature of the relevant issue area, events in international or national politics and relations, the need for favorable access to the international market, etc. Promising work on this concept has recently emerged from both the activist and the scholarly communities. For example, Transparency International, an organization that pursues an anti-corruption agenda, publishes a Bribe Payers Index (BPI) that ranks the frequency of incidences of corruption by both country and industry, a tool of great practical value to activists who seek to predict the receptivity of a target state on a given issue. Terry Karl finds that overreliance on petroleum exportation causes petro-states to follow a specific institutional and political trajectory, regardless of their domestic mode of governance or international commitments. Generally, these and similar efforts support the notion that greater specification of terms and concepts would be beneficial to scholars and activists alike. 
CASE ANALYSIS: OCP, 1989 - 2003

\section{Actors and Institutional Capacity.}

In 1989, CEPE was reorganized as Petroecuador, and became sole operator of SOTE. Informal negotiations for the OCP began during the same year. The original OCP Consortium was comprised of Alberta Energy, Kerr McGee, Occidental Petroleum, AGIP, Perez Companc, Repsol-YPF and Techint. ${ }^{75}$

In 1992, Ecuador withdrew from OPEC, in preparation for the augmentation of its production capacity. Although a series of expansions had increased the carrying capacity of the SOTE to some 390,000 barrels per day, transport capacity reportedly fell short of production potentials; the new pipeline promised a capacity of 450,000 barrels per day, more than doubling Ecuador's output. ${ }^{76}$

The OCP project was associated with a trend towards external and institutional involvement in the effort to assess the project's potential impacts; this was a departure from the agential nature of discovery and information dissemination of the SOTE era. One reason for this shift was the difference in project scope, and thereby in potential impact. Also important was the increasingly salient issue of liability for negative environmental impact.

Until the mid 1990s, the state consistently dealt with negative environmental

\footnotetext{
${ }^{75}$ AmazonWatch, New Oil Pipeline, 2003.

${ }^{76}$ Veldman, 1.
} 
impact through informal and case-specific arrangements. In the few instances in which the state imposed environmental standards on the hydrocarbon industry, it did so through arrangements with individual companies rather than through wholesale adjustments of its legislation or the strengthening of its institutional enforcement capability. For example, the 1993 filing of Aguinda $v$ Texaco prompted Texaco and the state to reach an agreement for the remediation of Texpet's negative environmental impact. Announced in 1995, the settlement cost Texaco a mere $\$ 40$ million, obligated the company to cleanup only 156 of its 627 unlined toxic waste pits, and provided the company a pretext for the renewal of its motion to dismiss Aguinda $v$ Texaco. ${ }^{77}$ The government certified Texpet's remediation in 1998 and thereby released the company from future liability. However, the state neglected to subsequently update its environmental standards through legislative or regulatory means, allowing instead for the continuation of those same laws that had permitted Texpet’s disastrous environmental practices.

A final reason for the institutional character of the OCP debate was the growing influence of non-governmental organizations. Beginning in the 1980s, non-domestic organizations representing social, political and scientific concerns established a presence in Ecuador. In the 1990s, indigenous rights and environmental organizations formed transnational alliances, resulting in expanded access to non-state intellectual and financial resources, and providing support for the creation and development of domestic counterparts. The domestic indigenous and environmental groups relied heavily on the technical, scientific, legal, and financial support of their international and regional counterparts.

While the majority of the international organizations engaged in sustained action

\footnotetext{
${ }^{77}$ Frente para la Defensa de la Amazonía, 1.
} 
over time, the occasional star has also appeared; in 2002, Julia Butterfly Hill joined activists in the Mindo Cloudforest for Ecuador's maiden tree-sit in protest against the government's approval for the routing of the OCP through the protected Mindo area. Such incidents aided in broadcasting the debate to the international arena. The interest generated abroad was particularly important to environmental policy evaluation since it expanded the epistemic community, or regime united in cohesive discourse, to include respected scientists whose research contributions reduced scientific uncertainty regarding the environmental effects of hydrocarbon activity. Significantly, this community produced the most thorough, and sometimes the only, EIAs of pipeline designs, siting decisions, and emergency response and mitigation policies.

One example is the contribution of The Mindo Working Group (MWG) to the debate over the siting of the pipeline. The OCP was largely designed to parallel the route of the SOTE, thereby containing invasive construction and maximizing knowledge about the potential problems of the OCP route. However, the state aggressively promoted a northern diversion of the OCP for a 100-mile stretch near Quito that would slice through the famously pristine and ecologically diverse Mindo National Cloudforest. The MWG found that the EIA for this "northern route” did not account for potential cumulative impacts, including: ${ }^{.8}$

- Encroaching cultivation

- Encroaching pastures

- Wood extraction for lumber and firewood

- Species (e.g., frogs) extinction in the Mindo region

- Increased forest fragmentation

- Noise related to pipeline construction

- Environmental degradation of the Mindo IBA

- Degradation of the water quality of the hydrographic basins

- Reduction in economic benefits

\footnotetext{
${ }^{78}$ Mindo Working Group, Section 4.6
} 
In a second example, additional concern over the Mindo route was voiced in a December 2001 letter from high-level World Bank officials that insisted the OCP consortium retract its unsubstantiated claim that the pipeline project was in compliance with World Bank standards. The letter was followed by perhaps the best example of influential, non-domestic evaluations of the OCP project: the 2002 report of the findings of Robert Goodland's Environmental and Social Impact Evaluations (EIA and SIA, or Social Impact Evaluation) of the OCP project.

Goodland, chief of the Environment Department of the World Bank for 25 years until his retirement in 2001, visited Ecuador in 2002 to complete the study that was "initiated by the German NGOs "Rettet den Regenwald" and "Urgewald" and supported by Greenpeace, the Institute Suedwind as well as several US and Italian NGOs and the three biggest Italian labor unions." ${ }^{, 79}$ In his report, Goodland accused the OCP consortium of substantial non-compliance with World Bank environmental and social criteria, namely Natural Habitats, Involuntary Resettlement, Environmental Assessment, and Indigenous Peoples. Goodland further confirmed that the alternative pipeline route promoted by activists was environmentally superior to the route (through the Mindo Cloudforest and the GEF's Choco-Andean Corridor) already approved by the state. ${ }^{80}$

Neither the World Bank nor Goodland was able to convince the state to reconsider the Mindo route. However, Goodland's condemnation of the pipeline project did cause Germany’s largest publicly-owned bank, Westdeutsche Landesbank (WestLB), to withdraw as the lead arranger of the original 17-year, \$900 million OCP syndicated

\footnotetext{
${ }^{79}$ Urgewald, 1; Goodland, 6.

${ }^{80}$ Goodland, 18-19.
} 
bank loan. ${ }^{81}$ Following the release of the Goodland report, network activists in Germany charged public officials, including the Prime Minister, from the German federal state of Nordhein-Westfalen (the bank's principal shareholder) with complicity. ${ }^{82}$ In Parliamentary hearings on the subject, Germany’s influential Green Party joined with NGOs in insisting that the WestLB honor the terms of its lending policy which required project compliance with World Bank environmental guidelines. ${ }^{83}$ Although the pipeline was by then largely completed, the WestLB withdrew completely.

In contrast to the trends towards specialization and diversification of knowledge through increasing foreign and substate institutional involvement, the state continued to centralize decision-making and to undermine environmental initiatives. The short-lived independence of DIGEMA followed this trend. In 1988, this agency began a campaign to strengthen hydrocarbon industry regulation. During this period, Conoco submitted Ecuador's first (if incomplete) EIA to DIGEMA. ${ }^{84}$ Article 31 of the 1990 Ley de Hidrocarburos [Hydrocarbon Law] reasserted that private and state-owned oil companies must submit detailed EIAs addressing all phases of operation. Yet, even as its responsibilities were reiterated, the DIGEMA was gutted and its responsibilities and resources were transferred to the Dirección Nacional del Medio Ambiente [National Directorate of the Environment, or DINAMA]. Both of these agencies were controlled by the new Subsecretaria de Medio Ambiente [Subsecretary of the Environment, or SMA], which was itself under the auspices of the MEM. Kimerling reports on the structural implication of the reorganization, stating that: the 1990 annual budget for the SMA was

\footnotetext{
${ }^{81}$ Van Gelder, 6.

${ }^{82}$ WestLB, 1; Goodland, 5.

${ }^{83}$ AmazonWatch, New Oil Pipeline, 2003; Hamilton.

${ }^{84}$ Kimerling, 2003, 81, 145.
} 
$\$ 10,000$; its four personnel were responsible for all of the extractive activities throughout the country; and none of the four was hired as a field-based compliance inspector. ${ }^{85}$

Not surprisingly, DINAMA's mandate to protect the environment was subordinated to the MEM's mandate to promote extractive industry activity. In 1990, the MEM developed a "gentleman's agreement” between the industry and the government, effectively bypassing the DINAMA. The Acta de compromiso para observer las disposiciones de manejo ambiental para las actividades hidrocarburíferas [Compromise Agreement for observing the environmental management rules for hydrocarbon activities] stated that industry compliance with environmental standards would be undertaken on a voluntary basis through 1992, at which time the issues of monitoring and enforcement would be revisited. ${ }^{86}$

Velasco succinctly describes the centralization of the bureaucratic structure as it was until 1995. He explains that the MEM’s SMA handled all development and regulation of sub-surface resources. The SMA had at its disposal three MEM agencies, which retained the following mandates: DINAMI (National Directorate of Mining) granted concession, exploitation and exploration permits; DINAMA (National Directorate of Environment) was primarily concerned with the environmental dimensions of resource development, received EIAs and was responsible for all monitoring, enforcement, etc.; and CODIGEM (Corporation for Geological-Mining-Metallurgical Research and Development) provided technical assistance to miners, and supported research and development. ${ }^{87}$

In 1995, a \$14 million World Bank loan to Ecuador’s established the Mining

\footnotetext{
${ }^{85}$ Kimerling, 2003, 81.

${ }^{86}$ Kimerling, 1991, 81, 148.

${ }^{87}$ Velasco, 2-3.
} 
Development and Environmental Control Technical Assistance Project. The Project Performance Assessment Report (PPAR) of 2003 found that institutional capacity was greatly undermined as a result of the bureaucratic structure, as described by Velasco. The World Bank noted that the centralization of decision-making and the existence of internal conflicting mandates were particularly troublesome. The PPAR concluded that:

When most environmental responsibilities are delegated to a sector ministry, as in Ecuador, it is important to reduce potential internal conflicts of interest between the sector ministry's roles as investment promoter and environmental control and enforcement agency, by clearly separating the responsibility for these functions. Furthermore, sector oversight capacity also needs to be built up within the Ministry of the Environment, and support of local communities needs to be secured. ${ }^{88}$

A 1996 executive decree created the Ministerio de Medio Ambiente [Ministry of the Environment, or MMA]. In 1997, the MMA began to act on its mandate: "gestor, asesor, promotor, concertador y ejecutor de las políticas ambientales” [facilitator, assessor, promoter, coordinator and executor of environmental issues $].^{89}$ In 1997, the state’s Agenda 21 report cast the creation of this multi-purpose agency as a move towards "integrated decision-making." ${ }^{, 90}$ In the same report, the state noted that its MEM funding had benefited from increased support from USAID and UNDP, but declined to declare its actual budget.

\section{Social and Environmental Impacts.}

Data for the amounts of crude spilled from the OCP are unavailable. However,

\footnotetext{
${ }^{88}$ Operations Evaluation Department, PPAR, 5.

${ }^{89}$ Government of Ecuador, 2002.

${ }^{90}$ Government of Ecuador, 2002.
} 
Weemaels provides information about spillage impacts on local residents that can be treated as a proxy measure of spillage; although they are not quantitative, her findings demonstrate that spillage events have been consistent and widespread. Weemaels reports that Acción Ecológica’s independent EIA of pipeline impacts through March 2002 contains data collected through interviews with the thousands of people living in the direct path of the OCP. These data indicate that, of the total number interviewed, 89\% lost crops and $15 \%$ lost farm animals as a result of oil spillage from leeches or ruptures in the OCP. An additional 19\% reported the loss of infrastructure, such as fencing, roadways or pasture, as a result of the siting and a destructive construction process. ${ }^{91}$ Furthermore, soil erosion resulting from the deforestation of the OCP route and access roads caused severe flooding. Weemaels estimates the total damage suffered by interview respondents at $\$ 1,299,390 .^{92}$

Weemaels also notes those environmental impact costs that are not easily quantified in economic terms. For example, the EIA recorded contamination of drinking water in 157 water reserves, streams and wells. Weemaels claims that each instance of contamination was the result of "inadequate technology, negligence of the workers and lack of available funds for mitigation of the impacts. ${ }^{, 93}$ Weemaels also includes data on the loss of flora and fauna and of various animal species. Finally, Weemaels writes of "extensive evidence that a pre-determined plan was lacking, and that instead, decisions were being made along the way. ${ }^{\text {94 }}$ In support of this observation, she cites large campsites within protected areas, two roads not included in the EIA originally submitted

\footnotetext{
${ }^{91}$ Weemaels, 2002.

${ }^{92}$ Weemaels, 3-5.

${ }^{93}$ Weemaels, 5b, author's translation.

${ }^{94}$ Weemaels, 5a, author's translation.
} 
by Technit, and evidence of advanced construction directly over a fault line.

This last observation points to the need to make unapproved and unsupervised adjustments in response to unexpected physical realities. This is a reality of the construction process that is not accounted for in EIAs or other forms of preliminary planning, despite the fact that many design and construction companies acknowledge this as a legitimate and routine occurrence. For example, Hydroconsult, an engineering firm hired to consult on the OCP design for river navigation, acknowledges making ad-hoc adjustments to the OCP river route, as new information and conditions necessitated. The state did not oversee the construction process, essentially devolving responsibility to private companies.

Other secondary impacts noted by Weemaels have been addressed by the state and industry, although not necessarily in a manner acceptable to the TAN. For example, the Fundación Jatun Sacha was subcontracted by the OCP Consortium to direct its Proyecto Revegetación [Revegetation Project]. The Fundación collected information about the areas to be destroyed by OCP construction, and grew vegetation indigenous to these areas in greenhouses for later replanting. ${ }^{95}$ This strategy can neither repair damage to the ecosystem and the environmental services it supports nor pretend to account for all of the plant and animal species that will be endangered or driven into extinction; yet, this remediation was surely an unprecedented nod in the direction of conservationists, whatever its purpose or design.

Among the more notable TAN successes was its effect on state policy providing for the protection of Yasuní National Park. Scientists Concerned for Yasuní (SCY) learned from satellite imagery in 2005 that Petrobras had begun construction on an illegal

\footnotetext{
${ }^{95}$ Fundación Jatun Sacha, 1.
} 
access road in the buffer zone (of primary forest) of the Yasuní National Park. The SCY’s alarm at the prospect of a Yasuní access road was motivated by environmental concerns, like logging, that transcend the immediate impact of the road itself. Yasuní is a nationally protected area, an UNESCO BioSphere and the earth's most biodiverse forest. ${ }^{96}$ Finer sounded the alarm to the international community and claimed that it ought to oppose the road since it would "transect the territory of the Chiru Isla Quichua community living along the Rio Napo, and would enter the ancestral territory of the Huaorani, possibly even impacting an uncontacted community. ${ }^{\text {97 }}$ SCY's letter-writing campaign to protect the roadless integrity of Yasuní achieved positive results under the recently-instated President Alfredo Palacio and his appointee, Environment Minister Anita Alban. Acting on information provided by SCY, Alban notified Petrobras in 2005 that it did not have governmental authorization to construct the road. Alan cited "the lack of consideration of access alternatives that would minimize impact. ${ }^{, 98}$ In response, Petrobras sued the state for access; the lawsuit was rejected by the courts and Petrobras agreed in 2006 to adopt SCY's recommendation to access its concession within Yasuní by helicopter.

Despite this small success, the state has generally supported policies that have significant secondary environmental impact. It became a member of the World Trade Organization in 1996 with hopes of attracting private foreign investment and expanding export markets. ${ }^{99}$ In further preparation for increased oil production, the state, acting through CEPE, initiated three rounds of bidding for permits to newly established concession areas. Although all of these concessions were, at least partially, within

\footnotetext{
${ }^{96}$ Finer, 2004, 1.

${ }^{97}$ Finer, 2004, 1.

${ }^{98}$ Environment News Service, 1.

${ }^{99}$ Velasco, 1996.
} 
protected biodiverse areas, the state maintained that its constitutional right to subsurface resources enjoyed legal priority over environmental considerations.

Such controversial state policy might have been facilitated by continuing attacks on the validity of linkages between indirect environmental and human health impacts resulting from hydrocarbon activity. For example, while Texaco does not deny its environmental practices, as they are outlined in Aguinda v Texaco, the company holds that there exists no proven link between its practices and the negative impacts on human and environmental health. Texaco also mobilized an epistemic community in support of its position, but this strategy backfired when it was revealed that health workers from many countries had "signed a statement excoriating Chevron for buying full-page ads in Ecuador's major newspapers, in which paid scientific consultants cast doubts on studies linking oil development to adverse health effects in the Amazon.”100

The World Bank recently implemented the Environmental Management Technical Assistance Project (PATRA), which aims to support the MEM in developing "detailed environmental procedures, criteria, limits, and EIA guidelines for the petroleum sector" and strengthening its environmental assessment capacities. ${ }^{101}$

This effort to specify and codify policy is a step in the right direction, although it is a retroactive policy as far as the OCP campaign is concerned. In the end, it would seem that OCP campaign did appear to enjoy some success in its efforts to influence the dialogue about the pipeline project. However, on closer examination, few of its accomplishments are concrete gains. In fact, revegetation projects and other similar projects flowing from the state and the industry could be interpreted as aggressive efforts

\footnotetext{
${ }^{100}$ Breilh, 2005, CRSwire, 1.

${ }^{101}$ Badelon and Dahar, 16.
} 
to co-opt the language of the network, thereby deflecting criticism and neutralizing the networks' claim to moral authority.

\section{Analysis.}

The TAN was in a position of strength at the beginning of the OCP debate. Recalling Keck and Sikkink's independent variables, it can be said that the OCP campaign enjoyed extraordinary advantages: broad horizontal links, an enormous virtual audience, important international allies, effective framing and so on. However, a scrupulous application of the authors' approach requires mention of the internal challenges to network cohesion, and a faithful critique of Keck and Sikkink's formulation begs a discussion of the authors' limited portrait of TAN actors and their relationships.

The authors treat TAN actors in static terms: they are either international or national, either fully collaborating or not. Empirical findings from the Ecuadorian TAN case show that this leaves much to be desired. For example, what role was played by an organization known as COICA (Coordinating Body of Indigenous Organizations of the Amazon Basin)? Created in 1992 by a number of indigenous movements from nine South American countries, and aimed at promoting indigenous claims to land and autonomy, COICA was an international-level actor during the OCP era. As such, it represented a number of national movements that were variously integrated in their respective domestic political landscapes, and interacted directly with actors at both national and international circuits. It is not clear how this entity fits into Keck and Sikkink's conceptual map of TANs, since its members were simultaneously the recipients and the protagonists of TAN 
activism, and since COICA, as an organization, interacted with both TAN actors from the national and international level.

The horizontal and vertical interactions of COICA were important to its role in the creation of the Ecuadorian TAN. In its structure and stated goals, the organization represented national-level actors who championed indigenous rights. In this capacity, it was the creator and catalyst of a new campaign strategy that was quickly adopted on a global level; COICA was the first entity to publicly call for and achieve progress towards the strategic marriage of indigenous rights and conservationist campaigns. ${ }^{102}$ In a 1989 letter addressed “To the Community of Concerned Environmentalists,” COICA stated that indigenous peoples of the Amazon and environmental activists were natural allies, as both sought to preserve the Amazonian rainforest. The letter called for collaboration in order to "guarantee the future of the Amazon Basin, not only for our peoples, but also for humanity.”103

The letter and its declarations, commonly known as the Two Agendas, launched a new partnership and activist campaign strategy. The collaboration was formalized in May of 1990 when COICA hosted the First Amazon Summit Meeting Between Indigenous Peoples and Environmentalists, which concluded with the signing of the Declaration of Iquitos. ${ }^{104}$ In the following decade, numerous strategies for effective collaboration were published and discussed by both actors, and the support of the donors - then mostly private foundations and some multilateral agencies - was secured. It seemed then that, as stated in the World Wildlife Federation's 1996 Principles and Guidelines on Indigenous and Traditional Peoples and Protected Areas, "there is no inherent conflict

\footnotetext{
${ }^{102}$ Chapin, 19-20.

${ }^{103}$ Chapin, 19.

${ }^{104}$ Chapin, 20.
} 
between the objectives of conservationists and indigenous peoples.”105

Challenging such statements are several high-profile, intra-network disputes that point to some degree of organizational and ideological incoherence within the TAN. The problems inherent in attempting to fuse distinct goals were exemplified by the international non-governmental organization (INGO) scandal of 1990 in which

representatives of two U.S.-based non-governmental organizations, the National Resources Defense Council (NRDC) and Cultural Survival, met in secret with representatives of Conoco, in an effort to work out a compromise solution that would allow Conoco to proceed with exploration while providing some protection for the environment. ${ }^{106}$

These organizations promoted their own pragmatic agendas. Since they were convinced that that oil extraction was destined to continue it seemed prudent to collaborate with industry actors in order to gain some control over the environmental outcomes. What they proposed was a trade of sorts: in return for the 'green stamp' that Conoco sought from the NRDC, the company would establish a conservation fund that would be placed under the management of Conoco and the "independent policy makers, nominated by NRDC, Conoco, and other participating groups." ${ }^{\text {107 }}$ In addition, the NRDC representatives offered a survey of the positions that they suspected the other environmental NGOs and INGOs might adopt in response to the Conoco compromise, and strategized about how best to soften opposition and manufacture support.

The content of this meeting was leaked to the international community and a significant fall-out followed. Many indigenous network activists, who focused their efforts on securing a moratorium on oil development activity rather than simply

\footnotetext{
${ }^{105}$ Chapin, 20.

${ }^{106}$ Benjamin and Turner, 3.

${ }^{107}$ Sugarman and Knaus, 1.
} 
managing environmental impact, felt betrayed. ${ }^{108}$ In an ironic twist, the bad press prompted Conoco to withdraw completely from Ecuador; of course, the void created by its departure was soon filled by another oil company, Maxus, which was less interested to committing itself to environmental management compromises. ${ }^{109}$ The end result constituted a net loss for all of the Ecuadorian TAN activists.

Clearly, actors from the environmental and human/indigenous rights arenas brought to the campaign a number of compatible yet distinct concerns. Despite on-going collaboration, the strategies of the two activist groups occasionally reflected ideological differences, sometimes to the detriment of collective efforts and campaign efficiency. Were these difficulties fatal to campaign outcome? Although Keck and Sikkink’s writing does not indicate how the degree to which internal problems might impact network goals can be assessed, they do emphasize the importance of the public's perception of network activists. In fact, the criteria 'transparent relationships among activists' is included in one of their independent variables. Is it possible that the network's internal fissures were to blame for the negative outcome of the OCP campaign? Was this episode but one instance in the long history of the Ecuadorian TAN or should it be interpreted as a symptom of the network's internal weakness?

Moving beyond the specifics of the Ecuadorian case, Mato provides us with good reason to always investigate the goals of the INGOs involved in any TAN. He explains that the funding matters, since it causes INGOs to become dependent on the state that supports their existence and thereby creates incentives for them to represent their

\footnotetext{
${ }^{108}$ Benjamin and Turner, 2-3.

${ }^{109}$ Kane, 76.
} 
sponsor's concerns. ${ }^{110}$ Similarly, Chapin reports that INGO loyalties, goals and strategies vary with shifts in funding sources. He finds that, since the 1990s, private donors and foundations have been displaced by corporate and bilateral or multilateral agencies as the principal sources of INGO funding. This is most true for "the Big Three," as Chapin refers to them: The Nature Conservancy, World Wildlife Federation, and Conservancy International. ${ }^{111}$ Concomitant to the change in funding sources was a "strategic shift" in INGO behavior; increasingly, large INGOs are territorial and antagonistic in their dealings with one another, dismissive of their Third-World "partners," and given to compromise with their donors. ${ }^{112}$

Chapin notes that the previous efforts to collaborate with affected indigenous peoples, were also abandoned in the course of this restructuring of priorities and funding, as conservationist organizations realized that it was not in their financial interests to support indigenous strategies of resistance, which were often economically disruptive and physically violent in nature and frequently aimed at the organizations' "funding partners." ${ }^{113}$ In justifying their decisions to disconnect from the indigenous rights campaigns in favor of maintaining supposedly "apolitical” positions, the Big Three have issued statements that call into question the wisdom of their previous efforts to promote "native stewardship," arguing instead that "once indigenous peoples are given tenure to their lands, there is no assurance that they will work to conserve their biodiversity." ${ }^{114}$ In and beyond Ecuador, the dual-issue campaign uniting indigenous and environmentalist activists is fragile; yet in Ecuador it did not break down, but instead was reconfigured

\footnotetext{
${ }^{110}$ Mato, 23.

${ }^{111}$ Chapin, 22-23.

${ }^{112}$ Chapin, 25.

${ }_{113}^{113}$ Chapin, 26.

${ }^{114}$ Chapin, 26-27.
} 
along ideological lines.

Furthermore, despite internal problems, it was certainly during the OCP era that the network was seemingly at its largest and most dense, and therefore in its most powerful position relative to the target state. In 2003, Martin found that there were "over 200 NGOs (national and transnational) working in the Ecuadorian Amazon ...”115 Of course, only provisional conclusions can be drawn from such data under the formulation of Keck and Sikkink. Taken together, network density and size constitute the fourth of Keck and Sikkink’s independent variables affecting campaign outcome. Of all the elements of the authors' TAN theory, this is by far the most unspecified. The authors do not contextualize either term, leaving the reader to wonder what constitutes a 'large' or ‘dense’ network. Keck and Sikkink also do not establish a threshold of sufficiency for either concept. Therefore, while it is easy to claim that the Ecuadorian TAN was at its largest during the OCP era or to count INGOs, it is not possible to apply Keck and Sikkink's formulation to establish whether the TAN was sufficiently large or dense to influence the campaign outcome. Methodologically speaking, these terms pose a great challenge to a case study application of Keck and Sikkink’s formulation.

Density relates to the ties that exist between members of any single TAN. However, it is unclear which types of 'ties' are necessary or sufficient or both for effective campaigning. The scholarly community has reacted quite strongly to the use of this slippery terminology, particularly as it is used to describe an independent variable. The most common critique holds that it is necessary for theoretical purposes to specify the numbers and qualities of these ties. For example, Tarrow and McAdam find that the nature of ties within a network determines the manner in which a campaign is projected

\footnotetext{
${ }^{115}$ Martin, 72.
} 
from the domestic sphere into the transnational arena. They find that there are two distinct paths that this projection, or "scale shift" can occur, following from two mechanisms of projection that the authors refer to as relational diffusion and brokerage.

The former involves the

transfer of information along established lines of interaction, while brokerage entails information transfers that depend on the linking of two or more previously unconnected social sites. We argue that while diffusion is the more common route because it uses existing identities and ties and facilitates emulation, when borders are to be crossed and distant social actors brought together, brokerage is the more likely mechanism .... ${ }^{116}$

Thus, the authors emphasize that the presence or absence of existing ties within a network can impact the manner in which a campaign is made transnational. This is of significance for a number of reasons, not the least of which is that Tarrow and McAdam find a correlation between the route taken to the transnational arena and the outcome of network activism. ${ }^{117}$

Tarrow and McAdam also briefly mention a variant of the first mechanism, one they call non-relational diffusion, meaning "the transfer of information by means of impersonal carriers, such as the mass media." 118 They explain that, while they think that such a pathway is a "common and important component of scale shift that has been woefully understudied by movement scholars," they decline to discuss it since their research program concerns the way in which "movement actors facilitate scale shift."119 This is unfortunate since mass media, particularly the internet, was extremely important to the development of the OCP campaign.

\footnotetext{
${ }^{116}$ Tarrow and McAdam, 145-6.

${ }^{117}$ Tarrow and McAdam, 145.

${ }^{118}$ Tarrow and McAdam, 127.

${ }^{119}$ Tarrow and McAdam, 127.
} 
Lance Bennett cautions against theories of network density and organization that do not factor in the use of "social technologies" like widely available open source applications on the internet. In contrast to Tarrow and McAdam's conceptualization of an impersonal mass media, Bennett writes that the term social technology indicates that it is not only the technology itself, but also its social dimensions that together facilitate scale shift. ${ }^{120}$ Bennett finds that virtual networks are in fact more personal and better defined by interpersonal ties than are the traditional NGO-based networks. He supports this argument by stating that virtual networks are less centralized, and therefore more reliant on the individual activist; this means that there is less need to censor radical opinions in order to allow an organization to present a moderate, public-friendly image. Bennett also makes the excellent point that the persons who have contributed the most to the development of alternative mass media are also likely those who were "least likely to have a voice in conventional media channels." ${ }^{, 21}$ Since virtual networks do not require network ties with traditional mass media formats, but only the technological capability to mount an internet campaign, it appears that there is a need to theoretically redefine the value of network density or, at the least, to explore whether strategic ties, for example to the conventional mass media, are inclusive or exclusive forces within networks.

Clearly, Bennett does not view the internet as yet another activist tool, having the same theoretical value as other mass media. In fact, he finds that, "more than amplifying the mobilizing capacities of organizations, application of social technologies are beginning to transform organizational forms," integrating so-called hyper-organizations, or internet-based networks, with the more traditional forms described by Keck and

\footnotetext{
${ }^{120}$ Bennett, 205.

${ }^{121}$ Bennett, 222.
} 
Sikkink. ${ }^{122}$ In essence, he advocates for a new theory of transnational activism that accounts for the intersection of these two groups, and for the possibility that such interaction will produce a hybrid organization that is, in practice and in theory, an unique entity.

The debate over organizational definition and form is actually concerned with best to maximize density in order to achieve access to the international system: via a decentralized virtual network, the loose and fluid network described by Keck and Sikkink, a strictly institutionalized framework, or some combination thereof? Keck and Sikkink envisioned an organizational structure allowing for fluid relationships between NGOs and INGOs of all sizes. Rather than developing institutionalized patterns of interaction, these network actors would collaborate on an as-needed basis, depending on the issue at hand. They write that "despite the differences between domestic and international realms, the network concept travels well because it stresses fluid and open relationships among committed and knowledgeable actors ...”123 Quoting Walter Powell, an organizational theorist, the authors claim that "networks are 'lighter on their feet' than hierarchy."124

Several arguments in favor of institutionalized relationships have surfaced in counter to this claim. Most of these hold that institutions are more efficient than loose networks since institutionalization enhances a network's access to the international system. This access facilitates the flow of resources and information, providing a mechanism for inter-network disputes, enhancing network legitimacy and ensuring its inclusivity, and reducing the effects of asymmetrical power relationships among network

\footnotetext{
${ }^{122}$ Bennett, 218.

${ }^{123}$ Keck and Sikkink, 8.

${ }^{124}$ Powell in Keck and Sikkink, 8.
} 
actors. Reduction of transaction costs is obviously important to the longevity and success rate of network activism. Also interesting is the suggestion that network might benefit from providing channels for democratic conflict resolution. Recalling earlier discussion, it is clear that Keck and Sikkink have adopted a limited and somewhat rosy characterization of network activists and their relationships; channels for intra-network dispute resolution might contribute to the success rates of TAN campaigns by enhancing legitimacy and transparency.

Advocating for the benefits of the de-centralized virtual network, Bennett predicts that both traditional NGO-centered and virtual networks will oppose the trend towards hybrid organizing. As he describes it, the conflict centers around which of the favored organizational forms, centralized or not, ought to dominate, and how the ideological and theoretical differences between these forms translate into real and practical dilemmas for network members. ${ }^{125}$ For example, a centralized, NGO-based approach draws heavily on institutional channels in order to achieve favorable terms of access to the international system, while the virtual networks create new, untapped channels of access, combining the benefits of large membership with complete flexibility. Such a network is associated with the additional benefit of computer-supported network measurement capabilities. Software designed to measure various qualities of virtual social networks has proliferated as internet-based networking sites have grown in popularity. Application of these methodological tools might enhance the usefulness formulation of Keck and Sikkink’s fourth independent variable.

In addition to its hybrid traditional-virtual form, the OCP campaign was also innovative in its approach to the idea of "material leverage.” Interestingly, it would seem

\footnotetext{
125 Bennett, 214-215.
} 
that the OCP TAN had the greatest impact on state policy making where it was able to create a new form of material leverage, rather than relying on traditional sources provided by pre-existing international actors. For example, the Ecuadorian case suggests that it might be theoretically useful to investigate the seeming emergence of "boomerang patterns” that involve domestic, foreign and international courts. In the case of Ecuador, this pattern is demonstrated by the filing of Aguinda v Texaco in New York; this court's eventual decision that the case should be heard in Ecuador; and a subsequent rush of transnational activism to promote the transparency, independence and authority of the suddenly famous and certainly overwhelmed Ecuadorian court in Lago Agrio. As Kolker describes it, Aguinda v Texaco represents a "pioneering new paradigm of exporting American-style environmental class actions., ${ }^{126}$

Interestingly, the campaign's innovative, court-based actions led indirectly to policy changes by the Ecuadorian government. During the 1990s, liability issues raised in the course of the initial hearings of Aguinda v Texaco prompted the state to supplement informal arrangements with formal mechanisms. Thus, the1994 decree Políticas Ambientales Básicas del Ecuador [Basic Environmental Policies in Ecuador] introduced the idea that foreign companies ought to "apply the highest standards and requirements of their home country in their operations in Ecuador, without prejudice to compliance with Ecuadorian law."127

The state was further galvanized by the specter of liability when it was proved that the1998 issuance of remediation certification to Texaco was based on fraudulent soil samples provided by the company. A flurry of lawsuits followed: the state maintained

\footnotetext{
${ }^{126}$ Kolker, 1.

${ }^{127}$ IACHR, 5.
} 
that this evidence annulled Texaco’s release from liability, while Texaco pointed out that the state had approved its method of sampling and its analysis of the results. At stake in this on-going legal tug-of-war is the assignment of responsibility for the social and environmental damages alleged in Aguinda v Texaco. It is entirely possible that the state, through its enabling policies and the low social and environmental standards of the staterun CEPE, might eventually be punished for ignoring the demands of the OCP campaign.

The potential leverage of class-action torts is significant. The current price tag attached to Aguinda v Texaco stands at $\$ 6.1$ billion, yet this suit only addresses damages sustained by 30,000 indigenous people from a few of tribes. Depending on the outcome of this suit, the threat of new class action suits could constitute a significant leverage. Thomasson emphasizes the potential scope of the liability issue, stating that:

Jota, et. al. $v$ Texaco, another class action suit on behalf of 25,000 Peruvians, was filed a few days after the Aguinda litigation had commenced. . . . The Jota plaintiffs claim that Texaco's oil operations in Ecuador also have had an impact in Peru. The Center for Economic and Social Rights, an NGO based in New York, has found that oil-related contamination flowed into Peru via the rivers common to the two countries. ${ }^{128}$

This suit illustrates that not only do environmental problems ignore political boundaries, but any associated liability might also cross borders. Increasingly, indications abound that creating leverage through creative applications of international law might constitute a new TAN strategy. Amazon Watch reports that "other companies recently targeted by "class action style" environmental litigation in Latin America include Dole Food, Shell Oil, Dow Chemical, Occidental Chemical, Del Monte Fresh Produce and Chiquita Brands International."129 Watts also acknowledges this emerging trend, noting that "Earthrights International, a nongovernmental organization (NGO), brought charges

\footnotetext{
128 Thomasson, 5.

129 AmazonWatch, 2003, 1.
} 
against Unocal arguing that the Yadama pipeline had led to extensive human rights abuses, specifically rape, death, and the disruption of a local way of life.... These clashes between a global oil industry and a vast transnational human rights advocacy network have become increasingly commonplace.”130

However, the success of these manufactured forms of leverage is as yet debatable. For example, the Ecuadorian state demanded that its contract for the construction of the OCP include a "guarantee payment of all environmental liabilities caused by the pipeline up to a maximum of $\$ 50$ million.”" ${ }^{\prime 31}$ The OCP Ltd. is also reported to have obtained a provision in its contract with the Ecuadorian government for three separate insurance policies, including “An Environmental Damage insurance policy, which covers all environmental damages resulting from the construction or operation of the pipeline."132

These measures, establishing and limiting liability, can be seen as a reaction to the potential liability of the SOTE era. However, they clearly prioritize state and industry concerns about environmental damage over those of the TAN; this outcome cautions against the tendency to assume that learning on the part of the target state will promote a convergence towards a single norm. In the case of Ecuador, the learning process simply alerted the target to its Achilles' heal and thereby enabled the continuation of its offensive behavior. The value of a reactive, legalistic and punitive action strategy is questionable, and possibly as likely to benefit as to deter the target.

In spite of such grim warnings, the prospect of creating new forms of leverage grows ever more tantalizing as traditional leverage increasingly fails to produce meaningful outcomes. The most obvious example of the OCP campaign's use of

\footnotetext{
${ }^{130}$ Watts, 374-5.

${ }^{131}$ Van Gelder, 12.

${ }^{132}$ Van Gelder, 12.
} 
traditional material leverage was the Goodland Report which supported the World Bank’s position and caused the WestLB to withdraw its support. This outcome follows perfectly the boomerang pattern described by Keck and Sikkink: network actors petitioned an actor from the international scene for assistance, and then used the information generated by this process to pressure the financial institution (via implicated politicians) to honor its public commitment to not bankroll infrastructure projects that did not meet World Bank environmental and social standards.

However, this event is most accurately thought of as a single battle won in the course of a war; it had little secondary impact on other actors or their policies. The reality of the international system and the global political economy in particular is that, while it allows for the simultaneous existence of multiple norms, it favors those orientations that prioritize capital accumulation. Acknowledging this structural complexity, it is hardly surprising that the financial impact of WestLB's departure was easily absorbed by the Consortium and its financial backers who remained beyond the influence of the TAN's demands. To underscore this point, it is worth examining how project financiers were able to operate freely, safely removed from the arena of contention, even as their OCP project was heavily criticized.

According to Van Gelder, the OCP project was funded through a combination of corporate equity and debt financing. The OCP Ltd. contributed US 400 million, or 31\% of the project costs; this was the parent company of OCP Ecuador S.A., the builder of the pipeline, which included corporate shareholders from seven different countries and was registered in the Cayman Islands. ${ }^{133}$ The remainder of the project cost, \$900 million, was secured through loans from "a group of 16 financial institutions from eight countries"

\footnotetext{
${ }^{133}$ VanGelder, 5-6.
} 
including nine banks and seven pension funds and insurance companies. ${ }^{134}$ In order to reduce investment risk, the financiers established contractual relationships with the OCP Consortium oil companies; the latter were made to sign 20-year "ship-or-pay" contracts guaranteeing payment to OCP Ltd. for a specified percentage of pipeline volume capacity regardless of actual production or transportation rates. The fact that all of these actors are transnational companies that originate or are based in a dozen countries complicates the advocacy network's task.

The financial web, and consequently the network's challenge, is further complicated by Ecuador's 2002 legislation requiring all OCP Consortium companies to pay a levy of US 1.20 per barrel of oil transported through the pipeline, the revenues from which are directed into an oil stabilization fund. ${ }^{135}$ As Van Gelder correctly notes, the policy makes clear that state "has a direct interest in the construction of the OCP pipeline."136 This incentive has been reinforced by the state's association with the International Monetary Fund (IMF) and other international finance institutions, particularly in so far as these institutions have predicated future lending to the state on its willingness to adopt certain economic and environmental policies in support of oil industry activity in Ecuador. Beginning in 2000, legislation revamped this fund as part of a series of IMF structural adjustment programs in Ecuador with the eventual result that $70 \%$ of all OCP revenues deposited in the fund are committed to servicing the country's external debt and an additional 10-20 \% are put into an "interest bearing deposit account held overseas which will be drawn upon only in the event that oil prices fall below a

\footnotetext{
${ }^{134}$ Van Gelder, 6-8.

${ }^{135}$ Van Gelder, 11.

${ }^{136}$ Van Gelder, 11.
} 
benchmark price.”137

A more immediate result of the 2000 Ley de Transformación Económica del

Ecuador [Economic Transformation Law, or Ley Trole I] was to establish legal provisions for the construction of the OCP. ${ }^{138}$ Failure to comply with this IMF requirement would have compromised Ecuador's ability to receive a pending IMF loan as well as future loans from international sources at a time when its external debt exceeded $\$ 16$ billion. ${ }^{139}$ Clearly the interests of the state have been shaped by those of its creditors.

Despite their influence, creditors and other international actors are largely absent from the most direct confrontations involving TAN actors (and from the literature that investigates these contentious actions) while states are often placed in the center of such conflict. This may be a result of certain campaign strategies such as establishing short, causal links and vilifying the target. However, this is not necessarily an effective approach for two reasons.

First, the state is caught in a vicious cycle of fragmentation, collapse and reconstitution. For example, Latin Finance noted in 2002 that "During the 30 months it took to design the financial structure for the Oleoducto de Crudos Pesados (OCP) pipeline and find backers for the project, Ecuador went through three presidents and nearly half a dozen finance ministers, defaulted on its Brady bonds and Eurobonds, suffered a military coup and adopted the US dollar as its national currency.”140

Furthermore, the state may intentionally cleanse itself of officials who draw fire from important international actors. For example, Rafael Correa (current President of

\footnotetext{
${ }^{137}$ Babelon and Dahan, 14.

${ }^{138}$ Finer and Huta, 1.

${ }^{139}$ Fischer, 4.

${ }^{140}$ Latin Finance, 1.
} 
Ecuador) resigned from his post as the Economy Minister in 2005 following intense national and international scrutiny of his plan to direct a larger percentage of the OCP oil stabilization fund towards social spending, or more precisely, away from the IMF. ${ }^{141}$ As noted previously, such a shifting political character undermines institutional maturation and frustrates attempts to establish accountability.

Second, a state in a position of compromised sovereignty, such as that in which Ecuador finds itself, is likely to be incapable of resisting the demands of international actors holding significant material leverage. The targeted state, caught between mutually exclusive demands, must weigh the relative significance of a possible loss of legitimacy against a potentially punitive reaction from the external system. One likely outcome of this dilemma is exemplified by the OCP case: the state does not challenge its position in the external political order and relies for continued internal control on its monopoly on coercive force, engaging its military and police forces to act in the supposed national interest.

Regardless of case-specific details, it is clear that all states must account for fact that the international arena is replete with power inequalities that constrain viable options and promote self-replication. The bottom-line implication for TAN effectiveness and predictive theorizing is clear: the combination of competing norms and unequal power structures is certain to challenge and likely to undermine the importance of any form of leverage, whether moral or material, that a network can expect to gain over a target state.

Finally, even where effective leverage is fully available to a TAN, one can ask whether outcomes produced by such TAN strategies are meaningful. This line of argument takes aim at the piecemeal strategy of the TAN campaign by questioning

\footnotetext{
${ }^{141}$ IFIs Latin American Monitor, 1.
} 
whether campaign successes (i.e. individual policy changes) can be expected to have a cumulative impact on the target's orientation or, more importantly, on the political structure that supports the target's offensive behaviors. To couch this point in Keck and Sikkink's language, the issue is whether individual campaign successes can truly promote a shift in norms, such that changes to the target's policies translate into an adjustment in its fundamental priorities and self-definition, which in turn contributes to the consolidation and expansion of particular international norms.

Keck and Sikkink’s static conceptualization of the international system and its actors did not lead them to comment on these challenges. However, as the idea of transboundary environmental issues has grown in popularity, other scholars have realized the importance of addressing the splintered nature of the international arena and the uneasy coexistence of multiple norms. For example, Sari has contributed to an on-going discussion of the possibility of creating an international environmental-human rights ombudsman. Zarsky, advisor to Sari, has presented ten case studies that collectively demonstrated a need for such an international actor, and detailed a proposal for the establishment of the position. The development of a central control charged with efficiently managing and resolving national environmental issues could perhaps assist in homogenizing the norms that inform the behavior of international actors, with increased campaign effectiveness deriving from more efficient inter-level articulation as one of the potential benefits accruing to advocacy networks. Of course, a concentration of control would likely be a solution most attractive to those actors interested in reinforcing current structural power relations. A more promising solution would entail the institutionalization of TAN norms by actors whose interests can only be fully realized within a context that 
prioritizes non-commercial values. In the Ecuadorian example, COICA most closely resembles such an institution; its experiences warrant close observation by theorists. In general, it follows from the analysis of the effectiveness of various strategies practiced by the Ecuadorian TAN and from the wide-ranging visions provided by scholars that TANs are theoretically capable of pioneering strategies and conceptual approaches to advocacy that have the potential to encourage new patterns of interaction. It is not clear that this capability can consistently be translated into action or, assuming they can be put into practice, whether their individual impacts might be cumulative. Furthermore, given the potential for organizational change (witness the evolution of COICA) and the certainty of contextual change (as in the growing popularity of virtual advocacy), it remains to be seen whether Keck and Sikkink’s formulation will continue to be relevant to future generations of activists and scholars. 


\section{FINAL DISCUSSION}

As promised, this paper has pointed to a number of underlying conceptual problems. While this exercise was not meant to fully address such concerns, it remains appropriate at this juncture to gather and summarize these issues for the benefit of present clarity and future research.

One central theme has been the existence of an international political and economic structure which prioritizes values that are hostile to environmental preservation and non-selective respect for social and cultural diversity. This is not meant as an attack on the capitalist system; indeed, extensive environmental and social damages have been perpetrated by states of all economic and political stripes. However, the current international system actively promotes the notion that national development can only be obtained by the prioritization of unregulated, capitalistic economic policies. The national interest has been defined in purely economic terms, and the state has been encouraged to adopt a corporate mindset in service of this supposedly singular purpose. Thus, the state finds no value in ecological integrity or social harmony that cannot be expressed in dollars and cents; instead, caring for the environment is regarded as restricting activities in support of capital accumulation and reducing profits by internalizing costs.

The state’s obligation to earn money has overrun any alternative conceptualization of state responsibility or purpose, such as that as the guarantor of the 
civil and human rights of its citizens or as the steward of the environment and other common goods. As a result of this orientation, states are amenable to policies that attract industry and foreign investment, even where this occurs at the expense of the citizenry and the national environment. For example, a state might view its unprotected labor force, environmental haven (weak regulations and lax enforcement) policies and weak or nonextant environmental agencies as comparative advantages that attract industry and thereby justify the social or ecological abuses that are written into such policies. ${ }^{142}$ Most disturbing is a state's willingness to violate its own laws or commit its military or police to the protection of industry; such extreme (yet common) policies effectively constitute a transfer of political power from state to industry.

Furthermore, where the state in question is located within the Third World, its tendency towards dependency on resource-intensive development is reinforced by the economic power structure of the international system. In particular, the unequal relationship between First and Third World economies favor the former as provider of capital and technical resources and as the designer of trade and other economic policies. Bryant and Bailey characterize this imbalanced relationship as one reminiscent of colonial times, when the 'progress' supported by IFIs (International Financial Institutions) "was measured in terms of trees felled, valleys flooded, minerals extracted and acreage dedicated to cash crops or cattle ranching." ${ }^{\text {143 }}$ Noting that IFIs promote structural adjustment programs that encourage states to their view natural resources as untapped economic reserves, the authors reaffirm that IFI policies result in double damage: first by lending in support of development projects that have negative

\footnotetext{
${ }^{142}$ Bryant and Bailey, 40, 60.

${ }^{143}$ Bryant and Bailey, 89.
} 
environmental and social consequences and then by demanding that indebted states make payment on project loans “... by cashing in natural resources.”144

External debt, resource-intensive development and state dependency on multinational corporations (for foreign direct investment, technical expertise and infrastructure development) together result in a self-replicating economic necessity, prioritization of corporate values, and state complicity in the consequences of unconstrained industrial activity. ${ }^{145}$ Once caught in this cycle, a state that abandons environmentally degrading or socially oppressive development projects risks that international creditors will remove it from the economic life support system. ${ }^{146}$ Given that the external structure demands a state to adopt a corporatist orientation, can responsibility be assigned to a state? Is there a chance that advocates can impact state orientation or does the state's articulation within the international system have a deterministic effect that renders a target unwilling, if not incapable, of responding to advocacy? If so, should activists focus on their efforts on First World states or IFIs in hopes of a trickle-down effect or, as Tarrow might say, a normative cascade? ${ }^{147}$

First, it is clear that, in theory, a state can select from among a number of orientations with respect to its citizens and natural environment. The fact that options exist is demonstrated by empirical evidence of a range of state orientations and documented by organizations like Transparency International and MAR which conduct comparative research and construct databases. The availability of alternative orientations is also a staple concept in theoretical work; for example, Bryant and Bailey find that there

\footnotetext{
144 Bryant and Bailey, 60, 91.

145 Bryant and Bailey, 115.

146 Bryant and Bailey, 59.

147 Tarrow, 2005, 143.
} 
is a "central paradox in the state's function,” meaning that a state can and must choose to act as either the steward or destroyer of the natural environment. ${ }^{148}$

Second, how can advocates encourage the target state to embrace an orientation that does not prioritize development above all other values? While the strategies enumerated by Keck and Sikkink are certainly important and useful, these will be most effective where they are utilized in order to promote ideas and visions of alternative realities. The size and economic prowess of a select number of INGOs notwithstanding, the power of a network comes primarily from its ability to initiate a public dialogue and to introduce interpretations that diverge from and challenge the official discourse and logic. The definition of campaign success must be reevaluated: the standard expectation that multiple policy changes will cause a norm shift is best read in reverse. Recalling the close association between IFI lending, fraternity of state and industry, and social and environmental injustice, the thought that a succession of disjunctive policy changes and uncoordinated advocacy in various “issue areas” might result in wholesale normative change on the part of the target should be discarded in favor of a holistic approach.

In general, the design of a campaign should flow from an understanding of the relative position of the target within the external power structure. This variable matters enormously for campaign outcome since targeting an economically dependent state does not alter the power imbalances that encourage the state to adopt offensive policies and since, in such circumstances, looking to the international arena for traditional leverage is inherently illogical.

These suggestions for improved campaign effectiveness have meaning for the enhancement of the predictive power of TAN theories. First, the problems of defining,

${ }^{148}$ Bryant and Bailey, 55, 114. 
measuring and evaluating campaign success should be clarified prior to data collection and analysis. In order to allow for true comparative research, Keck and Sikkink’s treatment of success as a campaign-specific and policy-centered variable should be replaced with a more standardized and meaningful conceptualization. Second, theories must account for the implications of the unequal power structure of the international system, or at least offer a theoretical specification and a measurement of target dependency.

A case study should begin with the widest lens available in order to understand the target's position within its larger context; from such an angle, it should be possible to assess the external risk to the target should it choose to comply with network demands. If a given risk level does not essentially immobilize the target, then analysis on the state and sub-state levels may follow. However, where the state is severely constrained by the external structure then theorists must consider the possibility that no campaign, no matter its framing choices or density, can impact the orientation of the target unless it also challenges the larger structure. Clearly, the international dimension should factor prominently in future transnational advocacy network theory building. 


\section{RESEARCH PROPOSAL}

As noted in the literature review, Keck and Sikkink too often resort to operationalizing actors in static and dichotomous terms. Relying on such broad conceptualizations surely increases the possibility of broad application of the TAN theory by allowing for a large universe of relevant cases. However, by undermining specificity of concept definition in order and thereby increasing generalizability, the authors have sacrificed predictive power.

The TAN theory assumes that democratic states will react to pressures from within and without in particular and predictable ways. In fact, Keck and Sikkink’s own description of the 'boomerang pattern' of activism implies that the target state features a mixture of democratic and undemocratic policies. Thus, their theory demands that the concept be expanded to encompass more than blanket democracy (or not). A more useful conceptualization will rely on a number of indicators of the accessibility of the state. To this end, the democratic nature of a given state might be assessed via indicators of substate actors' access to the state, such as:

1) Formal channels for public participation, including a transparent electoral system, referendums, and procedures for the redress of grievances (i.e. civil and constitutional courts).

2) Informal channels, including congressional lobbying, civil right to strike and publicly 
demonstrate, and public forums for dialogue between officials and citizens.

Keck and Sikkink acknowledge the importance of international leverage, yet they do not offer a method whereby the relative importance to the target of various leverages can be assessed. Ideally, these leverages, which condition the preferences of the target and thereby its decision-making, should be ranked by their importance to the state; this could be achieved on a case-specific basis by employing a rational choice modeling of external pressures and state preferences. However, a generally applicable approach should also be articulated.

To this end, indicators of state vulnerability should be categorized according to the nature of the repercussions that the state will suffer should it choose to not respond as requested. For example, the Ecuadorian state hoped to borrow extensively to fund the OCP project; the activists worked to tie project funding to international environmental standards, while the IMF tied all future funding for Ecuador to the completion of the OCP; the state was able to secure the funds needed for the pipeline project despite the departure of WestLB; therefore, the repercussions of not complying with IMF pressures regarding the OCP were more far-reaching than the repercussions for ignoring activist pressures. Essentially, it is inappropriate to assume that any state will reflexively submit to international pressure; conversely, it is reasonable to expect that a state will respond to the incentive structure created by pressures from various international actors. The central idea here is that different sources and articulations of international pressure should be expected to have different meanings for the target state and therefore varying impacts on state responsiveness. The following baseline indicators for assessing state vulnerability serve as a starting point: 
1) Extensive reliance on external assistance from international actors who tie the terms of their current and future support or penalties to particular state behaviors and policies. 2) Ratification of international commitments that impose penalties on member states for violations of their provisions.

3) Signature of international commitments carrying non-compliance penalties; or ratification or signature of international commitments not carrying non-compliance penalties.

Hypothesis. Changes to the independent variables necessitate a slight reformulation of Keck and Sikkink’s hypothesis statement, as follows:

1) A network cannot influence state policy where positive response by the target state to network pressures carries possible repercussions for the state which outweigh potential benefits.

2) A network can only succeed where it is sufficiently large and dense to create public awareness of the campaign and its message.

3) Positive public perception of the campaign (belief in the reliability of the campaign members and the content of the campaign message) is a necessary, but not sufficient, condition for a network to succeed in influencing state policy.

Data Collection. Adoption of the preceding recommendations complicates data collection. For example, case selection cannot draw from data sets that rely on democratic procedural minimums to score states as democratic or not. However, data collection certainly remains possible. There are a number of data sets that can be used as a sample pool and might also serve in the development of a case-specific rational choice model. For example, Transparency International hosts a public-use data set that scores 
citizen and private sector perceptions of state corruption; such data could support a rational choice preference specification that claims that substate activists are unlikely to expect that they can influence their state, and therefore are prone to seek external alliances. Reporters Without Borders hosts a 'Worldwide Press Freedoms Index’ that measures press freedom from state intervention; this data could be used to support an argument about the lack of informal venues for citizen participation and expression. The United Nations, a body that frequently sponsors international agreements, publishes lists of state members to international agreements and explanations of relevant noncompliance penalties. A number of accessible sources, including the multilateral financial institutions, publish information related to the external debt and other factors impacting the national economy. Inter-state trade information is also widely available. Measurement of Network Characteristics. As indicated in the literature review, researchers have expressed substantial frustration with the methodological challenges of measuring the size and density of a transnational network. The difficulty is quite clearly inherent in the task.

The crucial problem is the difficulty of establishing a valid measure of 'density.' This is partly caused by the vagueness of Keck and Sikkink's terminology; some scholars have interpreted density to mean the number of contact points (interactions) between actor1 and actor2, while others find that counting contact points without establishing the frequency or extent of actor interaction. An ideal operationalization of the 'density' variable should interrogate the nature of network members' interaction. A case-specific approach might utilize a survey designed to measure interaction quality. Survey questions might investigate whether actors share their human and financial resources, whether there 
actors are aware of a hierarchy among them, or how contact was initially established or sustained over time.

However, a more generally useful approach is necessary. Two pragmatic measurements, one each for the virtual and the face-to-face network dimensions, can guide the development of an approach with broader utility. To measure the latter, the presence of at least one 'umbrella organization,' or voluntary grouping of many organizations into a single unit, is an excellent indicator of the presence of a network. Furthermore, the coverage (or number and diversity of the groups that are represented by the umbrella organization) provides a measure of complexity and density.

The virtual dimension is an important aspect of any contemporary transnational network, and one completely ignored by Keck and Sikkink. The internet presents unique challenges to and opportunities for the measurement of network density and size. One solution known as "link analysis" developed out of network analysis. Essentially, this method relies on those internet search engines, including Google, that are designed to rank search result pages according to "how many links point to the page." ${ }^{\text {"149 }}$ Thompson explains that the number of links to any given page is an indicator of its importance to other on-line users and pages. Therefore, link analysis suggests that the ranking of the returns on a Google search is indicative of the density of connections to that page. Larson sums up the argument by stating that

Social network analysis holds great potential for identifying and analyzing social phenomena that might otherwise not be visible. Its most enduring contributions make use of a fundamental assumption that things are better understood in relation to other things in their environment. That is, rather than hoping to uncover the essence embodied by an entity B whether person, group, or society B SNA looks for meaning in the relations between entities. ${ }^{150}$

\footnotetext{
149 Thompson, 60.

150 Emirbayer in Larson, 4.
} 
Conclusions. This study has established that Keck and Sikkink’s formulation did not offer substantial predictive value in the case of the Ecuadorian OCP TAN. Empirical application and theoretical debate support the conclusion that this theoretical weakness stems from a superficial treatment of the international structure in which all states are embedded. It therefore seems misguided and unreasonable to wholly assign either blame or credit for a campaign outcome to the network itself, as is the tendency in the relevant literature.

It is not necessary to completely abandon Keck and Sikkink’s original formulation. It is far more valuable to problematize and expand on the authors' original independent variables so that these become more useful indicators of the complexity of the international system and enhance the ability to theoretically account for a wider range of variation on the dependent variable. All instances and outcomes of transnational activism are complicated by network interaction with the larger system that is characterized by uneven distributions of power. Theories of transnational advocacy should direct attention to the possible impacts of this interaction on advocacy campaign outcomes. Furthermore, it is possible to access data in support of the expanded research design making this a viable alternative design. If successful, the research proposed herein might enhance the predictive power of Transnational Action Network theory. 


\section{REFERENCES}

Aguinda v Texaco, Inc., 142 F.Supp.2d 534 (S.D.N.Y. 2001)

AmazonWatch. CorpWatch : ChevronTexaco Faces Trial in Ecuador for Rainforest Destruction. May 6, 2003. CorpWatch, [cited March 25, 2007]. Available from http://www.corpwatch.org/article.php?id'6691

AmazonWatch. Ecuador: Amazon Oil Expansion and the OCP Pipeline. 2003 [cited August 25, 2007]. Available from http://www.amazonwatch.org/amazon/EC/ocp/index.php?page_number’1.

AmazonWatch. January 2003. Ecuador: New Oil Pipeline Threatens Fragile Ecosystems and Communities from Amazon Rainforest to Pacific Coast. [cited March 25, 2007]. Available from http://www.rainforestinfo.org.au/ocp/background.htm.

AmazonWatch. Eostar 2002. "Fighting the Oleoducto de Crudos Pesados Tree by Tree: Protecting the Ecuadorian Forest." Earth First! Journal 22 (4). [cited March 25, 2007]. Available at http://www.earthfirstjournal.org/articles.php?a’715

Amnesty International. February 2004. Death Threats/Fear for Safety: Members of Fundación Pachamama, a human rights organization (Index AMR 28/005/2004). [cited March 25, 2007]. Available from http://web.amnesty.org/library/Index/ENGAMR280052004?open\&of'ENG-398

Amnesty International. 2005. Annual Report Entries: Ecuador. [cited March 26, 2007].

Anaya, S. James. 1996. Indigenous peoples in international law. New York: Oxford University Press. Available from http://web.amnesty.org/report2005/ecusummary-eng

Andolina, Robert. 1994. "Second Indigenous Uprising Secures Concessions on Agrarian Reform." Abya Yala News. [cited March 25, 2007]. Available from http://ecuador.nativeweb.org/vida_94/andolina.html

Arsel, Murat. "Transnational Advocacy Networks in the Mediterranean: The case of nuclear energy in Turkey." Chicago, IL: Environmental Studies Program, 
University of Chicago. [cited March 25, 2007]. Available from http://environment.uchicago.edu/studies/pdfs/turkey.pdf.

Babelon, D. and C. Dahan. January 5, 2003. Evaluation of the World Bank Group's Activities in the Extractive Industries, Background Paper, Ecuador Country Case Study. Operations Evaluation Department, World Bank.[cited August 24, 2007]. Available from http://www.ifc.org/ifcext/oeg.nsf/AttachmentsByTitle /oed_cCs_ecuador/\%24FILE/oed_ccs_ecuador.pdf+establishment+oil+stabilizatio n+fund+ecuador\&hl'en\&ct'clnk\&cd'6\&gl'us\&client'firefox-a.

Barraclough, Solon L. and Fernando Eguren. 2001. "Chapter 8: Agrarian Reform Issues and Initiatives in Three Andean Countries in South America." In Whose Land? Civil Society Perspectives on Land Reform and Rural Poverty Reduction: Regional Experiences from Africa,Asia and Latin America, ed. Krishna B. Ghimire and Bruce H. Moore. Italy: Popular Coalition to Eradicate Hunger and Poverty, United Nations Research Institute for Social Development (UNRISD).

Beltrán, Bolívar and Jim Oldham. Spring 2005. Ecuador - Oil companies' links with military revealed. Las Lianas: Resource Center for Science, Culture and Environment. [cited August 26, 2007]. Available from http://www.laslianas.org/updates/LLRCnews_2005-n1.pdf.

Benjamin, Craig and Terisa Turner. 1993. "Playing out a full hand: Indigenous people's movements and the vulnerability of the transnational energy corporations." Paper written for Indigenous People: The Way Forward. Malaysia: University Kebangsaan. [cited March 25, 2007]. Available from http://www.uoguelph.ca/ terisatu/chapter_8.htm

Bennett, Lance. 2004. "Social Movements Beyond Borders: Organization, Communication, and Political Capacity in Two Eras of Transnational Activism." In Transnational Protest and Global Activism, ed. Donatella della Porta and Sidney Tarrow. Boulder: Rowman \& Littlefield.

Breilh, Jaime et al. 2005. "Texaco and its Consultants." International Journal of Occupational and Environmental Health 11 (2):217-20.

Bryant, Raymond L. and Sinead Bailey. 1997. Third World Political Ecology. London: Routledge.

Butler, Rhett A. 2006. Oil Extraction: The Impact Oil Production in the Rainforest. Mongabay / A Place Out of Time: Tropical Rainforests and the Perils They Face. [cited March 25, 2007]. Available from http://rainforests.mongabay.com/0806.htm

Chapin, Mac. November/December 2004. A Challenge to Conservationists. World Watch Institute. [cited August 25, 2007]. Available from 
http://www.nativelands.org/PUBLICATIONS/Pub/A_Challenge_to_Conservation ists.pdf.

CONAIE. 2002. "Sixteen Demands Proposed by the CONAIE in the 1990 Uprising." In From Peasant Struggles to Indian Resistance: the Ecuadorian Andes in the late twentieth century, ed. A. Pallares. Norman: University of Oklahoma Press.

Coutsoukis, Photius. November 10, 2004. Ecuador: Social Classes - Peasants. [cited August 25, 2007]. Available from http://www.photius.com/countries/ecuador/society/ecuador_society_peasants.html

CSRwire. December 02, 2005. Chevron Shareholders Submit Resolution Addressing Ecuadorian Contamination Controversy. SRI World Group, Inc., [cited August 25, 2007]. Available from http://www.socialfunds.com/news/release.cgi?sfArticleId'4766.

De La Torre, Luis Carrera. 1995. "Review." In Electronic Green Journal 1(2). Translated by Janet Groff Greever, Robert Hook and Carolyn Hook. [cited March 24, 2007]. Available from http://egj.lib.uidaho.edu/egj03/carrer01.html

Delgado, Guillermo. January 21, 2000. Ecuador: Reflections on the January 2000 Popular Uprising. ISLA, Information Services Latin America. [cited March 25, 2007]. Available from http://isla.igc.org/SpecialRpts/Ecuador.html

EarthTrends, the Environmental Information Portal. 2003."Country Profile: Ecuador." Washington DC: World Resources Institute. [cited March 25, 2007]. Available from http://earthtrends.wri.org/pdf_library/country_profiles/bio_cou_218.pdf

Encyclopedia of the Nations. 2006. Americas: Ecuador: Energy and Power. Thomson Gale [cited August 25, 2007]. Available from http://www.nationsencyclopedia.com/Americas/Ecuador-ENERGY-ANDPOWER.html.

Energy Solutions. February 03, 2005. OCP Ecuador Chooses Energy Solutions' Pipeline Transporter to Manage Oil Movements. Energy Solutions. [cited March 25, 2007]. Available from http://www.energy-solutions.com/press_releases /03FEB2005.htm

Environment News Service. May 03, 2006. "Ecuador: Rainforest Road Scheme Blocked by Government." [cited March 25, 2007]. Available from http://www.bgci.org/worldwide/news/218/

Farrah, Douglas. May 15, 1992. "Ecuador Cedes Amazon Land To Indians; President Issues Titles Following Heated Conflict." Washington Post: a.30. Washington, D.C.: Washington Post Company. 
Finer, Matt. April 28, 2004. Oil Companies Poised to Penetrate Ecuadorian Amazon. Environmental News Service. [cited March 25, 2007]. Available from http://www.ens-newswire.com/ens/apr2004/2004-04-28-insfin.asp.

Finer, Matt and Leda Huta. May/June 2005. "Yasuní Blues: The IMF, Ecuador and Coerced Oil Exploitation." In Multinational Monitor, 26 (5\&6). [cited March 25, 2007]. Available from http://multinationalmonitor.org/mm2005/052005/finer.html

Fischer, Stanley. May 19, 2000. Ecuador and the IMF. [cited March 24, 2007]. Available from http://www.imf.org/external/np/speeches/2000/051900.htm\#P9_23

Flores, Edmundo and Tim Merrill. 1991. "Ecuador: Natural Resources and Energy." In A Country Study: Ecuador, ed. D. M. Hanratty. Washington, D.C.: Federal Research Division, Library of Congress.

Frente Para La Defensa De La Amazonía. 2007. Aguinda v Texaco, Jota v Texaco: Q\&A. Frente Para La Defensa De La Amazonía. [cited March 25, 2007]. Available from http://www.texacorainforest.com/why/questions.html.

Fundación Jatun Sacha. "Proyecto Revegetación del Oleoducto de Crudos Pesados (OCP)." [cited March 24, 2007]. Available from http://www.jatunsacha.org/espanol/ocp.htm

Goodland, Robert. September 2002. "Ecuador: Oleoducto de Crudos Pesados (OCP), (Heavy Crude Oil Pipeline): Independent Compliance Assessment of OCP with the World Bank’s Environmental and Social Policies." [cited March 25, 2007]. Available from http://www.unfarallon.info/pdf/Bladexgoodland.pdf

Government of Ecuador. 2002. "Institutional Aspects of Sustainable Development in Ecuador." In Agenda 21: National Sustainability Reports: UN Department of Economic and Social Affairs, Division for Sustainable Development. [cited March 25, 2007]. Available from http://www.un.org/esa/agenda21/natlinfo/countr/ecuador/inst.htm

Grawemeyer Award, University of Louisville. December 01, 1999. 2000 - Margaret E. Keck and Kathryn Sikkink "Activists Beyond Borders". University of Louisville, Grawemeyer Award. [cited March 27, 2007]. Available from http://www.grawemeyer.org/worldorder/previous/00.htm.

Hamilton, Gina. "The Amazonian Oil Wars." [cited March 24, 2007]. Available from http://www.rainforestinfo.org.au/ocp/1000\%20words\%20canada.htm

IACHR, Inter-American Commission on Human Rights. April 1997. "Report on the Situation of Human Rights in Ecuador, Chapter IX: Human Rights Issues of Special Relevance to the Indigenous Inhabitants of the Country," Docuament 10, OEA/Ser.L/V/II.96. Country Reports. Organization of American States. 
IACHR, Inter-American Commission on Human Rights. April 1997. "Report on the Situation of Human Rights in Ecuador, Chapter VIII: The Human Rights Situation of the Inhabitants of the Interior of Ecuador Affected by Development Activities," Document10, OEA/Ser.L/V/II.96. Country Reports. Organization of American States.

IFIs, Latin American Monitor. August 22, 2005. The resignation of Rafael Correa, Ecuador's Economy Minister: an example of IFI s influence? Third World Institute: Choike. [cited March 24, 2007]. Available from http://ifis.choike.org/informes/123.html

International Labor Organization. June 27, 1989. "Convention (No. 169) on Indigenous and Tribal Peoples in Independent Countries,” Article 14 (1)."

IWGIA, International Work Group for Indigenous Affairs. 2005. The Indigenous World: 2005. Edited by Diana Vinding y Sille Stidsen. Copenhagen: IWGIA.

Johnson, Ian and David de Ferranti. December 19, 2001. "Letter to the OCP Consortium." Washington, D.C.: The World Bank. [cited March 24, 2007]. Available from http://www.crbm.org/modules.php?name'download\&f'visit\&lid'53

Kane, Joe. 1996. Savages. New York: Vintage Books.

Karl, Terry Lynn. 1997. The Paradox of Plenty: Oil Booms and Petro-States Berkeley: University of California Press.

Keck, Margaret E. and Kathryn Sikkink. 1997. Activists Beyond Borders : Advocacy Networks in International Politics. Ithaca, N.Y.: Cornell University Press.

Kennedy, Jr., Robert F. 1991. "Preface." In Amazon Crude, by Judith Kimerling. New York: Natural Resources Defense Council.

Kimerling, Judith. 1991. Crudo Amazónico. Translated by Rodney Youman and Raúl Pardo. Quito, Ecuador: Abya Yala.

Kimerling, Judith. 1996. "Oil, lawlessness and Indigenous struggles in Ecuador's Oriente." In Green guerrillas : environmental conflicts and initiatives in Latin America and the Caribbean : a reader. ed. H. Collinson. London: Latin American Bureau : Distribution in the USA: Monthly Review Press.

Kimerling, Judith, Susan S. Hendriksen, and Natural Resources Defense Council. 1991. Amazon crude. New York: Natural Resources Defense Council. 
Knudson, Tom. April 27, 2003. "Chapter One: Staining the Amazon." In State of Denial, A Special Report on the Environment, ed. Rick Rodriguez: Sacramento Bee. [cited March 25, 2007]. Available from http://www.sacbee.com/static/live/news/projects/denial/c1_1.html

Kolker, Carlyn. 2006. “Jungle Warfare.” Global Litigation/Cases. Litigation 2006: A Supplement to the American Lawyer and Corporate Counsel. [cited March 31, 2007]. Available from http://www.jonesday.com/files/Publication/ed125e72-789f4e6c-b2cb-06c395f31d70/Presentation/PublicationAttachment/3c8b7fe9-3db743dd-ae14-15fa6af15e25/00111060009JonesDay.pdf

Laraia, Barbara, et al. 2003. "A Framework for Assessing the Effectiveness of Antihunger Advocacy Organizations." Health Education and Behavior 30 (6): 756-70.

Larson, Jeff A. 2004. "Social Network Analysis and Social Movements (Draft)." Tucson, AZ.: Department of Sociology, University of Arizona.

Latin Finance. 2002. "A Pipeline Pulls Through." Latin Finance (Year End Review: Project Finance Transaction 2001). [cited March 25, 2007]. Available from http://www.latinfinance.com/default.asp?Page'14\&PUB'30\&ISS'2633\&SID'102 247\&Country'\&SM’ALL\&SearchStr'OCP

Loveman, Mara. 1998. "High Risk Collective Action: Defending Human Rights in Chile, Uruguay, and Argentina." American Journal of Sociology 104 (2): 477-525.

Lucas, Kintto. May 23-29, 2002. "Anti-pipeline activists released from prison in Ecuador." Global Report No.175. Asheville, North Carolina. [cited March 25, 2007]. Available from http://www.agrnews.org/issues/175/environment.html

Martin, Pamela L. 2003. The Globalization of Contentious Politics: The Amazonian Indigenous Rights Movement, 45-80. New York: Routledge.

Mato, Daniel. 1997. "On Global-Local Connections, and the Transnational Making of Identities and Associated Agendas in Latin America." Identities: Global Studies in Culture and Power 4 (2): 167-212.

Mindo Working Group. April 10, 2001. "Rapid Ecological Assessment of the Proposed Northern Route of the OCP Heavy Crude Pipeline." Worldtwitch. [cited March 25, 2007]. Available from http://www.worldtwitch.com/rea.htm

MREE, Ministerio de Relaciones Exteriores del Ecuador. 2005. The Andes. MREE. [cited August 25, 2007]. Available from http://www.mmrree.gov.ec/mre/documentos/promocion/alianza/purest2.htm 
Operations Evaluation Department, World Bank Group. 2003. "Ecuador - Mining Development and Environmental Control Technical Assistance. Mining Development and Environmental Control Technical Assistance Project (Loan 3655 EC)." In Project Performance Assessment Report. World Bank Group, Sector and Thematic Evaluation Group, Operations Evaluation Department.

O'Rourke, D. and S. Connolly. 2003. "Just oil? The distribution of environmental and social impacts of oil production and consumption." Annual Review of Environment and Resources 28: 587-617.

Pieck, Sonja K. 2006. "Opportunities for transnational indigenous eco-politics: the changing landscape in the new millennium." Global Networks 6 (3): 309-29.

Pierson, Paul. 2004. Politics in Time: History, Institutions, and Social Analysis. Princeton, NJ: Princeton University Press.

Powers, Bill and Mark Quarles. 2006. "Texaco's Waste Management Practices in Ecuador were Illegal and Violated Industry Standards." In Chevron's Sham Science: Illegal Waste Dumping (Report): Critical Analysis of Chevron's Science: Submission 2. . Pichincha, Ecuador: Amazon Defense Coalition. [cited March 24, 2007]. Available from http://www.texacotoxico.org/eng/index.php?option'com_content\&task'view\&id' 35\&Itemid'66\&PHPSESSID’1c88bec536a3f8365f6e8e23d914d7de

Reporters Without Borders. WorldWide Press Freedom Index. Reporters Without Borders for Press Freedom. [cited March 25 2007]. Available from http://www.rsf.org/rubrique.php3?id_rubrique'639.

Reuters. January 28, 2001. "Ecuador oil pipeline bursts, spills oil into river." Reuters News Service. [cited March 24, 2007]. Available from http://www.planetark.org/dailynewsstory.cfm?newsid'9620

San Sebastian, Dr. Miguel and Dr Juan Antonio Córdoba. June 1999. "Yana Curi” Report: The impact of oil development on the health of the people of the Ecuadorian Amazon. Coca: Orellana: Vicariato Apostólico de Aguarico.

Sari, Agus P. 1998. "Ombudsman Function: A Case Study and a Methodological approach for a Global Environment and Development." In Environmental and Human Right Impacts of Trade Liberalization: A Case Study in Batam Island, Indonesia. San Jose, Cost Rica: Earth Council. [cited March 25, 2007]. Available from http://www.omced.org/cases/case_Sari2.pdf

Sikkink, Kathryn. 2005. "Patterns of Dynamic Multilevel Governance and the InsiderOutsider Coalition." In Transnational Protest and Global Activism, ed. Donatella della Porta and Sidney Tarrow. Boulder: Rowman \& Littlefield. 
Smithsonian Institution. 2007. Volcanoes of the World, Volcanic Activity Reports, Guagua Pichincha, Monthly Reports. Smithsonian Institution, Global Volcanism Program (2002-) [cited March, 25 2007]. Available from http://www.volcano.si.edu/world/volcano.cfm?vnum'150202'\&volpage’var\&VErupt'Y\&VSources'Y\&VRep'Y\&VWeekly'Y

Sowa, Jessica, Sally Coleman Selden and Jodi R. Sandfort. 2004. "No Longer Unmeasurable? A Multidimensional Integrated Model of Nonprofit Organizational Effectiveness." Nonprofit and Voluntary Sector Quarterly 33 (4):711-28.

Sugarman, Jim and Holly Knaus. 1991. "Behind the Lines: Environmental Sell-Out." Multinational Monitor 12 (5).

Tarrow, Sydney. 2005. The New Transnational Activism. Cambridge: Cambridge University Press.

Tarrow, Sydney and Doug McAdam. July 22-26, 2003. "Scale Shift in Transnational Contention." Written for Transnational Processes and Social Movements. Villa Serbelloni, Bellagio, Italy. [cited March 24, 2007]. Available from http://falcon.arts.cornell.edu/sgt2/contention/documents/ST\%20scaleshift\%20jun 04.doc.

Texaco. October 21, 2003. Summary of ChevronTexaco Response to Ecuador Lawsuit. [cited August 25, 2007]. Available from http://www.texaco.com/sitelets/ecuador/en/.

Thomasson, Denise. 1995. "Indigenous People File Suit Alleging Environment as a Human Right." Human Rights Brief 3 (1).

Thompson, Clive. 2006. "Open-Source Spying." New York Times Magazine, December 03, 2006: 54-61.

Transparency International. February 03 ,2007. TI Corruption Perceptions Index (CPI). Transparency International. [cited March 25, 2007]. Available from http://www.transparency.org/policy_research/surveys_indices/global/cpi.

Unfarallon. "Latin American Export Bank, SA (BLADEX): Oil and Ecuador." Unfarallon. [cited March 25, 2007]. Available from http://www.unfarallon.info/bladex.asp

United Nations Sub Commission on Prevention of Discrimination and Protection of Minorities. August 26,1994. "Draft United Nations Declaration on the Rights of Indigenous Peoples." Geneva: Office of the United Nations High Commissioner for Human Rights. 
Urgewald. 2002. "WestLB Pipeline in Ecuador: Slap in the Face from leading expert on World Bank Standards." [cited March 26, 2007]. Available from http://www.rainforestinfo.org.au/ocp/goodland.htm+goodland+OCP\&hl'en\&ct'cl nk\&cd'1\&gl'us\&client'firefox-a

US Department of State. March 31, 2003. Country Reports on Human Rights Practices: Ecuador - 2002. US Department of State, Bureau of Democracy, Human Rights, and Labor. [cited March 25, 2007]. Available from http://www.state.gov/g/drl/rls/hrrpt/2002/18330.htm.

Van Gelder, Jan Willem. January, 2003. "The financing of the OCP pipeline in Ecuador: A research paper prepared for Urgewald and Environmental Defense." [cited March 24, 2007]. Available from http://www.unfarallon.info/pdf/Bladex_OCP_financing.pdf

Velasco, Pablo. 1996. The Mineral Industry of Ecuador. US Department of the Interior, US Geological Survey. Updated March 21, 2007. [cited March 25, 2007]. Available from http://minerals.usgs.gov/minerals/pubs/country/1996/9511096.pdf.

Veldman, Wim. November, 2003. "Beyond the Norm: Ecuador Oil Pipeline." Hydroconsult. [cited March 25, 2007]. Available from http://www.hydroconsult.com/art/news/B_T_N.pdf

Watts, Michael J. 2005. "Righteous Oil? Human Rights, the Oil Complex, and Corporate Social Responsibility." In Annual Review of Environment \& Resources, 30: 374392. Portland, OR: Book News, Inc.

Weemaels, Nathalie. July 04, 2002. "Informe sobre los impactos de la construcción del Oleoducto de Crudos Pesados." Acción Ecológica. [cited March 24, 2007]. Available from http://www.accionecologica.org/webae/images/docs/petroleo/Impactos\%20Ambie ntales\%200CP.doc

WestLB. October 20, 2001. OCP Pipeline in Ecuador. [cited March 25, 2007]. Available from http://www.westlb.de/cms/sitecontent/westlb/ui/en/aktuelle_themen/ ocppipelineprojekt/presseinformation_ocp_65701.standard.gidN2FkNDZmMzU4OWFmYTIyMWM3N2Q2N2Q0YmU1NmI0OGU_.html.

WHO. 2000. "El Niño and its health impact," Fact Sheet No. 192, Document No. A68576. Geneva: World Health Organization, Office of Press and Public Relations. [cited March 25, 2007]. Available from http://www.who.int/mediacentre/factsheets/fs192/en/index.html

Wilkenfeld, Jonathan. December 31, 2003. MAR | Data | Assessment for Lowland Indigenous Peoples in Ecuador. Center for International Development and 
Conflict Management; University of Maryland. [cited March 25, 2007]. Available from http://www.cidcm.umd.edu/inscr/mar/assessment.asp?groupId'13003

Yánez, Ivonne. 2002. "resisting the pipeline in ecuador: chronicle of a disaster in the making " link magazine, friends of the earth international, Second Quarter (101). [cited March 25, 2007]. Available from http://209.85.165.104/search?q'cache:D_RT3MIHTesJ:www.foei.org/publication s/link/101/e1011011.html+Y\%C3\%A1nez+fault+lines+ecuador\&hl'en\&ct'clnk\& cd'1\&gl'us\&client'firefox-a

Zarsky, Lyuba. A Human Rights / Environmental Ombudsperson: Case Study Lessons and Design Recommendations. International Ombudsman Centre for the Environment and Development (omCED). [cited March 25, 2007]. Available from http://www.omced.org/om_nautilus.htm. 


\section{APPENDIX: ACRONYMS}

CEPE Corporación Estatal Petrolera Ecuatoriana Ecuadorian State Petroleum Corporation

CODIGEM Corporación de Desarrollo e Investigación Geológico-Minero Metalurgica Corporation for Geological-Mining-Metallurgical Research and Development

COICA Coordinador de las Organizaciones Indígenas de la Cuenca Amazónica Coordinating Body of Indigenous Organizations of the Amazon Basin

CONAIE Confederación de Nacionalidades Indígenas del Ecuador Nacional Confederation of Indigenous Nations of Ecuador

DIGEMA Direccion General de Medio Ambiente General Directorate of the Environment

DINAMA Dirrecion Nacional de Medio Ambiente

National Directorate of the Environment

ESMAP Energy Sector Management Assistance Programme (World Bank Group)

GEF Global Environment Facility

IERAC Instituto Ecuatoriano de Reforma Agraria y Colonización Ecuadorian Agrarian Reform and Colonization Institute

MEM Ministerio de Energía y Minas

Ministery of Energy and Mines

MMA Ministerio de Medio Ambiente

Ministry of the Environment

OCP Oleoducto de Crudo Pesado

Heavy Crude Pipeline

SCY Scientists Concerned for Yasuní 
SMA Subsecretaria de Medio Ambiente Subsecretary of the Environment

SOTE Sistema de Oleoducto Trans-Ecuatoriano

Transecuadorian Pipeline System 


\section{CURRICULUM VITAE}

NAME: $\quad$ Isabella Christensen

ADDRESS: Department of Political Science

Ford Hall

University of Louisville

Louisville, Kentucky 40292

DOB: Copenhagen, Denmark - March 14, 1977

EDUCATION AND TRAINING: B.A., Spanish, Cum Laude University of Louisville $2001-2004$

AWARDS: Graduate Dean's Citation

University of Louisville

2007

Erin Lyons Rouse Award

Department of Political Science, University of Louisville 2007

Graduate Assistantship

Department of Political Science, University of Louisville 2006 - 2007

Chancellor=s List

2006

New Mexico Graduate Scholars Award University of New Mexico

2006

INVITED PRESENTATIONS: Indiana Political Science Association 2007 Annual Meeting

Evansville, Indiana 


\section{CURRICULUM VITAE}

NAME: Isabella Christensen

ADDRESS: Department of Political Science

Ford Hall

University of Louisville

Louisville, Kentucky 40292

DOB: Copenhagen, Denmark - March 14, 1977

EDUCATION AND TRAINING: B.A., Spanish, Cum Laude University of Louisville $2001-2004$

AWARDS: Graduate Dean's Citation

University of Louisville

2007

Erin Lyons Rouse Award

Political Science Department, University of Louisville 2007

Graduate Teaching Assistantship

Political Science Department, University of Louisville

$2006-2007$

The Chancellor's List

2006

New Mexico Graduate Scholars Award

University of New Mexico

2006

INVITED PRESENTATIONS: Indiana Political Science Association, Annual Meeting Evansville, Indiana

2007 